\title{
12. GEOPHYSICAL MEASUREMENTS ALONG THE TRACK OF D/V GLOMAR CHALLENGER, LEG 26, DEEP SEA DRILLING PROJECT, SOUTHERN INDIAN OCEAN
}

\author{
Bruce P. Luyendyk, ' Department of Geology and Geophysics, \\ Woods Hole Oceanographic Institute, Woods Hole, Massachusetts
}

\section{INTRODUCTION}

Geophysical measurements of ocean depth, seismic structure, and the earth's magnetic field were made along the track of Glomar Challenger's 5600 nauticalmile voyage across the southern Indian Ocean. The track crossed many physiographic provinces, including abyssal plains, shallow banks and plateaus ("microcontinents"), spreading ocean ridges, deep ocean basins, and continental margins. In addition, the track traversed major portions of the African, Antarctic, and Indo-Australian lithospheric plates.

Navigation was mainly by satellite, with additional fixes by celestial means. A $12-\mathrm{kHz}$ transducer was used for echo-sounding and the magnetic field was measured with a proton precession magnetometer. Seismic reflection measurements were made with $5-\mathrm{in}^{3}$ and $30-\mathrm{in}^{3}$ airguns, fired in tandem, and received via a single-channel array.

Encoding of the navigational and geophysical data was completed at sea; the depths and total magnetic field were recorded every $5 \mathrm{~min}$. Depths are given at an assumed sound speed of $800 \mathrm{fm} / \mathrm{sec}$. The navigation and geophysical time series were processed digitally ashore, including keypunching and editing, by the Geological Data Center at the Scripps Institution of Oceanography. The magnetic anomaly was calculated relative to the IGRF of 1965.

All geophysical data obtained during Leg 26 are available to the scientific community, in accordance with the Sample Distribution Policy governing Deep Sea Drilling Project materials.

The account which follows serves mainly to point out some salient features of the geophysical data. The most important observations are associated with the profile from Sites 252 to 253 across the Southeast Branch of the Indian Ocean Ridge which shows virtually no sediment cover on its southern flank; also, this same profile shows a well-developed progression of sea-floor-spreading magnetic anomalies across the ridge. These had not been observed here previously.

The profile diagrams shown below employ the following conventions. Seismic reflection records are shown in seconds of two-way travel time (DT). Magnetic data are shown on an arbitrary scale rather than as calculated anomalies. This is because the IGRF for 1965 yields too high a value for the regional field. The magnetic profiles

\footnotetext{
'Now at Department of Geological Sciences, University of California at Santa Barbara, Santa Barbara, California.
}

along the ship's track are plotted with the track assumed to have the IGRF value. All profiles are at a constant time base with net distance between selected navigation points given in nautical miles. Gaps in the record ordinarily indicate course changes (i.e., no loss of data).

\section{DURBAN, SOUTH AFRICAN TO SITE 250 (Figures 1 and 2)}

This line crosses the African continental margin, the Mozambique Plateau and enters the Mozambique or Natal basin. Acoustic basement first appears on the Mozambique Plateau, but disappears at about $1.25 \mathrm{sec}$ DT subbottom in the Natal Basin. Basement reappears near Site 250 at $0.8 \mathrm{sec}$ DT subbottom, but it is not clear whether it is the same as that seen beneath the plateau. The floor of the Natal Basin shows sediment wave features which have been suggested to be the result of bottom current action (Ewing et al., 1969). The strong intermediate reflector near Site 250 is apparently not an expression of any lithologic change (see Site 250 report).

The magnetic field data show high anomalies not obviously generated by known polarity reversals. The magnetic profile over Site 250 shows a relative negative anomaly over the site (Figure 1). Paleomagnetic studies (Chapter 18, this volume) show a positive or normal polarity for the basalt at this site, in contrast with the field measurement.

\section{SITE 250 TO SITE 251 (Figures 1 and 3)}

The profile shown in Figure 3 crosses the Natal Basin, Madagascar Plateau, and the northern flank of the Southwest Branch of the Indian Ocean Ridge. Acoustic basement seen at Site 250 disappears a short distance along the track to the east. Basement reappears as an outcrop near 0400Z, 15 Sept., in the Natal Basin, and is visible along the rest of the profile up to Site 251. The track across the flank of the Southwest Branch suggests that the basement here consists of blocks with a component of northwards tilt. The presite survey near Site 251 (see Site 251 report) indicates a northeast-southwest grain of linear mountain ranges. Sediment cover is very variable along this track and generally thins up the flanks of the ridge. Basement apparently outcrops on several of the peaks on the Madagascar Plateau. The west flank of the Madagascar Plateau shows sedimentary structures-hills or dunes-which are suggestive of bottom current activity.

The magnetic field over the flank of the Southwest Branch is very weak and no sea-floor-spreading anomalies can be recognized. High-amplitude anomalies over the Madagascar Plateau suggest that this feature has a volcanic basement. 


\section{SITE 251 TO SITE 252 (Figures 1, 4, and 5)}

Figure 5 shows this profile traversing the Southwest Branch and entering the Crozet Basin. Acoustic basement is visible everywhere and is overlain by very transparent sediments which diminish in thickness to zero over the crest of the Southwest Branch. Sediment in the Crozet Basin is so transparent that the sea floor is nearly invisible between 1600 and 2000Z, 23 Sept. The ship evidently crossed the rift valley of the Southwest Branch, which shows a spectacular relief of 3000 fathoms. Alternatively, this trough might be a fracture zone across the crest, but topographic control in this region is not adequate to evaluate this possibility. Nicely shown on the profile of the southeastern flank of the Southwest Branch are tilted fault blocks extending down to where the ridge flank joins the Crozet Basin.

The magnetic profile across the Southwest Branch shows no sea-floor-spreading anomalies. There is no indication of a central anomaly across rift valley. Site 252 is on a positive anomaly (Figure 4).

This profile (Figure 5) shows the joining of the Southwest Branch and the Crozet Basin which is about $450 \mathrm{~km}$ due south of the ridge crest. Assuming a spreading rate of $1.0 \mathrm{~cm} / \mathrm{yr}$ in the north-south direction, the age of the Southwest Branch is about 45 m.y., or middle Eocene.

\section{SITE 252 TO SITE 253 (Figures 4, 6, 7, and 8)}

Figure 7 shows the geophysical profile out of the Crozet Basin and up the south flank of the Southeast Branch of the Indian Ocean Ridge. Very transparent sediments in the Crozet Basin thin to zero thickness near $1730 \mathrm{Z} 25 \mathrm{Sept}$. (Figure 7). The south flank of the Southeast Branch is virtually free of sediment. No satisfactory explanation of this observation can be offered. Several troughs, interpreted as fracture zones, were crossed on the flank of the ridge. These have not been traced using other data from the region. Sea-floorspreading magnetic anomalies can be seen on the south and north flanks of the Southeast Branch. In Figure 7, tentative identification of anomalies 5 through 21 (Heirtzler et al., 1968) is shown. Identification has been made by comparison with synthetic profiles (not shown) and published models in McKenzie and Sclater (1971), and Sclater and Fisher (in press). This profile is not projected normal to the strike of lineations (mainly because the strike is poorly known) but the spreading rate is about $3.0 \mathrm{~cm} / \mathrm{yr}$ up to anomaly 13 and about $4.0 \mathrm{~cm} / \mathrm{yr}$ from anomalies 13 to 21 . Some of the anomaly sequence appears missing between anomalies 13 and 21 and some is repeated between anomalies 6 and 12. Sediment cover first becomes significant between anomalies 13 and 18 . The sequence of anomalies shown in Figure 7 and 8 is presently being studied in more detail to analyze the spreading history of the Southeast Branch.

Figure 8 shows a crossing of the Southeast Branch crest and the track down the north flank into the Central Indian Basin and up the Ninetyeast Ridge. Notice that the northeast corner of Figure 7 is repeated in the southwest corner of Figure 8. In Figure 8 the sea-floorspreading anomalies have been identified by comparison with synthetic profiles shown by Sclater and Fisher (in press, fig $6 \mathrm{a}$ ) for this locality. The spreading rate is 2.5 $\mathrm{cm} / \mathrm{yr}$ but may have been higher prior to anomaly 13 . In this interpretation, a fracture zone near $2100 \mathrm{Z}, 30 \mathrm{Sept}$, (Figure 6) offsets the anomalies to the right at $84^{\circ} \mathrm{E}$. The location of the fracture zone, and the offset, was predicted by Sclater and Fisher (in press). This fracture zone may continue south to the crest of the Southeast Branch where it has been charted as the Yama Fracture Zone (McKenzie and Sclater, 1971). Anomaly 20 is interpreted by Sclater et al. (in press) to be $46 \mathrm{~m} . \mathrm{y}$. old, and therefore the age of Site 253 is the same as the crust on the Indian plate immediately to the west (see Site 253 report). Sediment cover on the north flank of the Southeast Branch is more widespread than on the south flank, appearing first near anomaly 5 (10 m.y.).

The anomaly polarity over Site 253 is indeterminate, but paleomagnetic studies give a normal polarity for the basalt basement (see above, Chapter 18).

\section{SITE 253 TO SITE 254 (Figures 6 and 9)}

This track follows the general strike of the Ninetyeast Ridge. The topography along the crest is highly irregular but with most summit depths between 800 and $1200 \mathrm{fm}$. The acoustic basement appears covered with a thin veneer $(0.1-0.2 \mathrm{sec})$ of transparent pelagic sediments, but as can be seen on close inspection (also Site 253 and 254 reports) the apparent basement overlies a still deeper reflector. The first strong reflector is an ash sequence, while the lower one is a sequence of basaltic flows.

The magnetic field has steep, high-amplitude anomalies attesting to the volcanic origin of this structure. The magnetic anomaly over Site 254 is positive but the basalt magnetization indicates a very stable reversed polarity (Chapter 18).

\section{SITE 254 TO SITE 255 (Figures 6 and 10)}

This line is a track eastward off the Ninetyeast Ridge structure and onto Broken Ridge. Leaving Site 254, a rather thick $(0.5 \mathrm{sec}$ DT) section of pelagic sediments can be seen covering the Ninetyeast Ridge, but this sediment is almost gone from Broken Ridge. Sedimentary dune-like features are seen on Broken Ridge near 0800$1200 Z, 11$ Oct. Crossing the south scarp of Broken Ridge, the track passes over the $\mathrm{Ob}$ Trench, a long linear deep previously charted at the base of Broken Ridge (Heezen and Tharp, 1965).

The magnetic signature over Broken Ridge is as rough as that over Ninetyeast Ridge (Figure 9), suggesting that Broken Ridge may also have a volcanic origin. Site 255 appears located over a positive anomaly.

\section{SITE 255 TO SITE 256 (Figures 11 and 12)}

Figure 12 shows the track down the north flank of Broken Ridge and into the Wharton Basin. The thick $(0.8 \mathrm{sec}$ DT) stratified sequence seen on the flanks of the ridge is probably the post-Cretaceous pelagic-calcareous sequence sampled near Site 255 (see Site 255 report). This calcareous sequence gives way to a more opaque section in the Wharton Basin near 0000Z 14 Oct. Considering the depth of the Wharton Basin, this opaque section is probably deep-sea clays, such as sampled at 
Site 256, which were deposited below the carbonatecompensation depth. Acoustic basement first appears near 1200Z, 14 Oct., and can be correlated with the basalt sampled at Site 256. A well-defined trough was crossed both approaching and leaving Site 256 (Figures 12 and 13 ). The feature is tentatively identified as a fracture zone, trending nearly northeast (Figure 11). Sclater and Fisher (in press) have suggested fracture zones in the Wharton Basin which, in contrast, trend northsouth.

The magnetic signature along the track shows typical marine magnetic anomalies, but they cannot be easily identified. Considering the 105 m.y. age for basement at Site 256, the crust here should contain the Cretaceous uniform polarity zone (Larson and Pitman, 1972) and not demonstrate any correlatable anomalies. The anomaly over Site 256 is positive, which agrees with the normal polarity of the basalts here (see Chapter 18).

\section{SITE 256 TO SITE 257 (Figures 11 and 13)}

The line connects the two sites in the Wharton Basin. Significant features crossed include the fractured trough near Site 256, another possible fracture zone near 2000Z, 18 Oct., and a 1600-fm-high seapeak near 1000Z, 19 Oct. Acoustic basement is everywhere visible and is covered by variable thickness of sediment. The sediment section is very transparent except for discontinuous internal reflectors near the northern end of the profile.

The magnetic data show typical marine magnetic anomalies, which again cannot be correlated with any known polarity sequence. The anomaly over Site 257 is positive, although small. This agrees with the normal polarity indicated in the rock magnetism measurements (see Chapter 18).

\section{SITE 257 TO SITE 258 (Figures 11 and 14)}

Figure 14 shows the geophysical data gathered between Site 257 in the Wharton Basin and Site 258 on the Naturaliste Plateau. Acoustic basement can be traced from Site 257 to the base of the Naturaliste Plateau. Because we did not sample the basement on the Naturaliste Plateau (see Site 258 report), it is not known whether this basement is basalt. The sediment section thickens as the plateau is approached. The stratified sequence seen towards the center of the profile may indicate turbidites on the Perth Abyssal Plain. A strong internal reflector at $0.3 \mathrm{sec}$ DT subbottom on the plateau appears to outcrop on the north-facing slope down into the Wharton Basin at $0000 \mathrm{Z}, 25$ Oct. Based on drilling results, this reflector marks the top of a Cretaceous detrital sequence (see Site 258 report).

The magnetic field over the plateau shows highamplitude anomalies which suggest a volcanic origin for this structure. The anomaly over Site 258 appears negative.

\section{SITE 258 TO PERTH, AUSTRALIA (Figures 11 and 15)}

This line traverses the Naturaliste Plateau and the Australian continental margin. The acoustic basement return and the internal reflectors measured in the plateau fade when approaching the continental margin. The magnetic signature also fades, suggesting a deepening of volcanic basement.

\section{ACKNOWLEDGMENTS}

I thank J. G. Sclater for helpful discussions and comments. This work was supported by the Office of Naval Research, under Contract N00014-66-CO24I NR 083-004.

\section{REFERENCES}

Ewing, M., Eittreim, S., Truchan, M., and Ewing, J. J., 1969. Sediment distribution in the Indian Ocean: Deep-Sea Res., v. 16, p. 231248.

Heezon, B. C. and Tharp, M., 1965. Descriptive sheet to accompany physiographic diagram of the Indian Ocean: New York (Geol. Soc. Am., Inc.).

Heirtzler, J. R., Dickson, G. D., Herron, E. M., Pitman, W. C., and Le Pichon, X., 1968. Marine magnetic anomalies, geomagnetic field reversals, and motions of the ocean floor and continents: J. Geophys. Res., v. 73, p. 2119-2136.

Larson, R. L. and Pitman, W. C., III, 1972. World-wide correlation of Mesozoic magnetic anomalies and its implications: Geol. Soc. Am. Bull., v. 83, p. 3645-3662.

McKenzie, D. P. and Sclater, J. G., 1971. The evolution of the Indian Ocean since the Late Cretaceous: Geophys. J. Roy. Astron. Soc., v. 25, p. 437-528.

Sclater, J. G. and Fisher, R. L., in press. The evolution of the east central Indian Ocean, with emphasis on the tectonic setting of the Ninetyeast Ridge: Geol. Soc. Am. Bull.

Sclater, J. G., Jarrard, R., McGowran, R., and Gartner, S., in press. A comparison of the magnetic and biostratigraphic time scales: In von der Borch, C. C., Sclater, J. G. et al., Initial Reports of the Deep Sea Drilling Project, Volume 22: Washington (U.S. Government Printing Office). 
N

젖

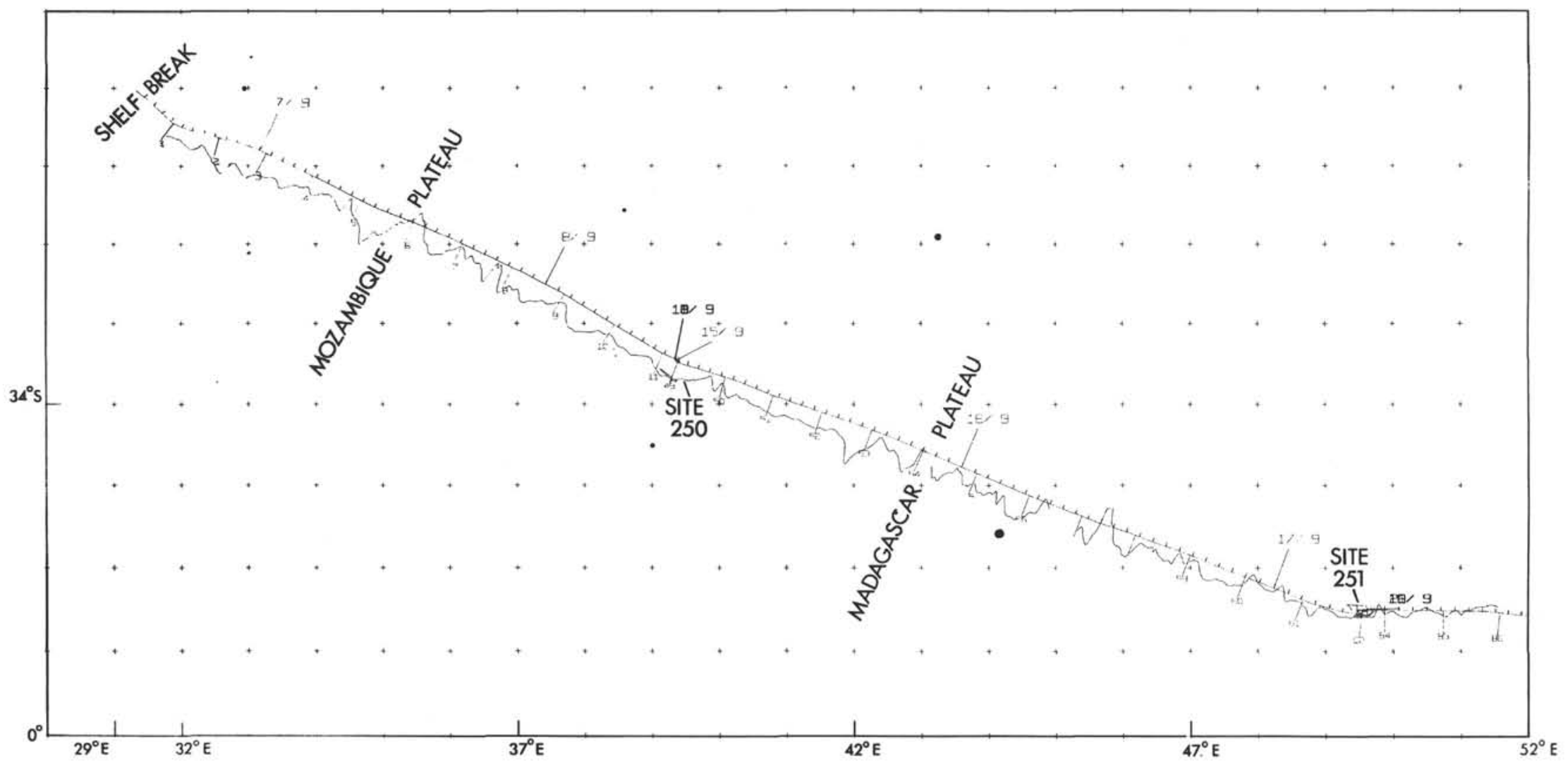

Figure 1. 

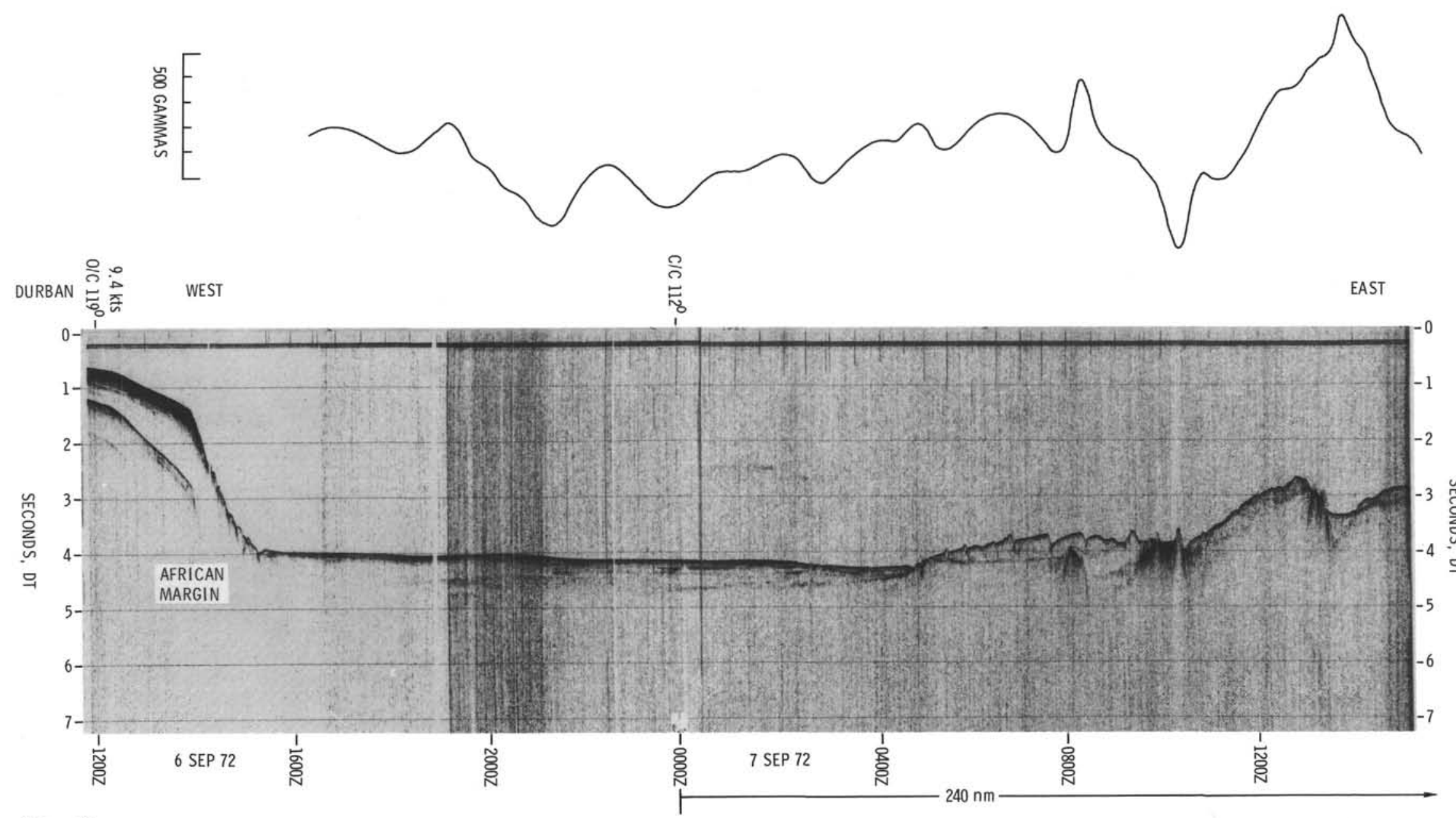

Figure 2. 


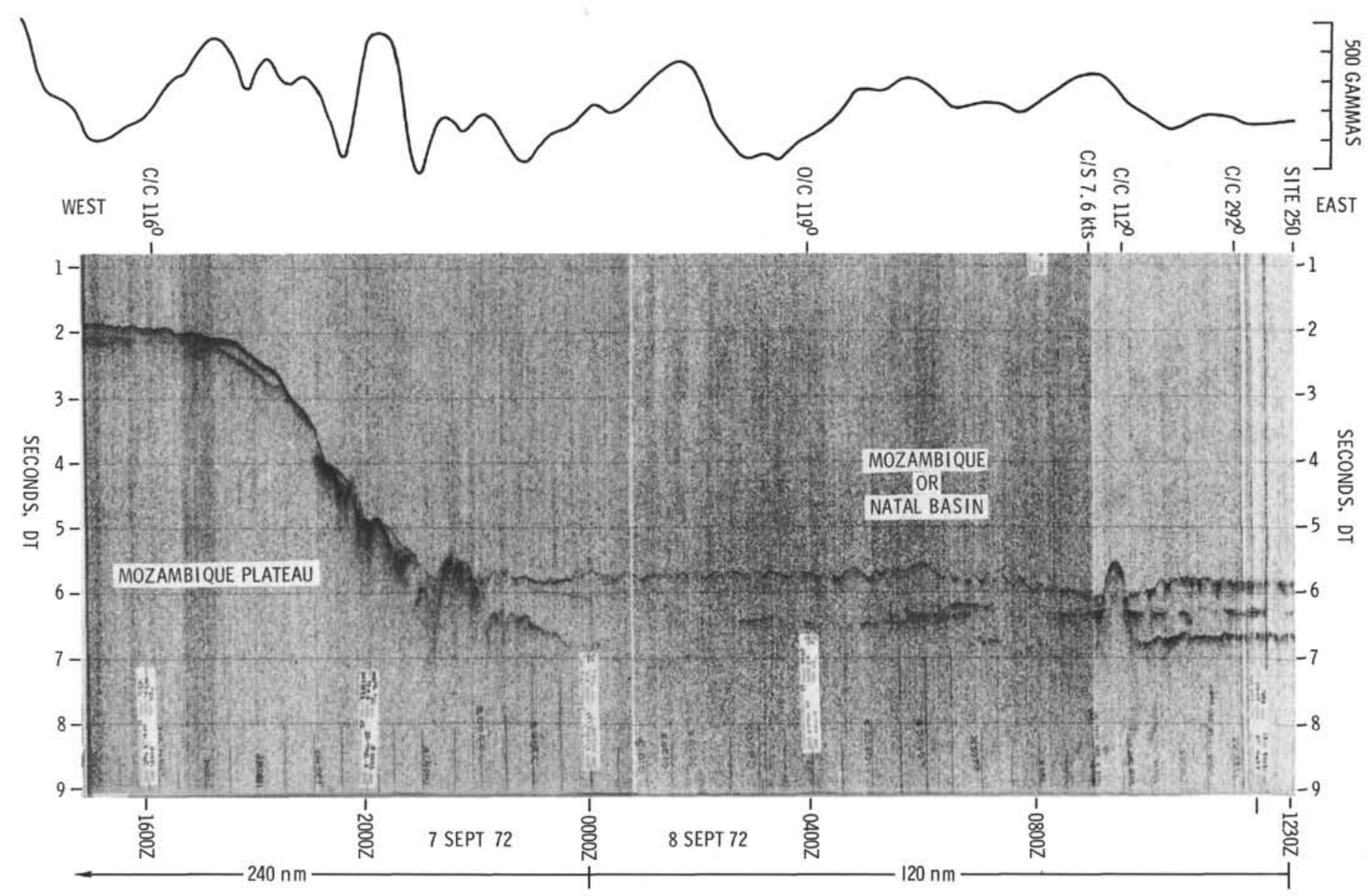

Figure 2. (Continued). 


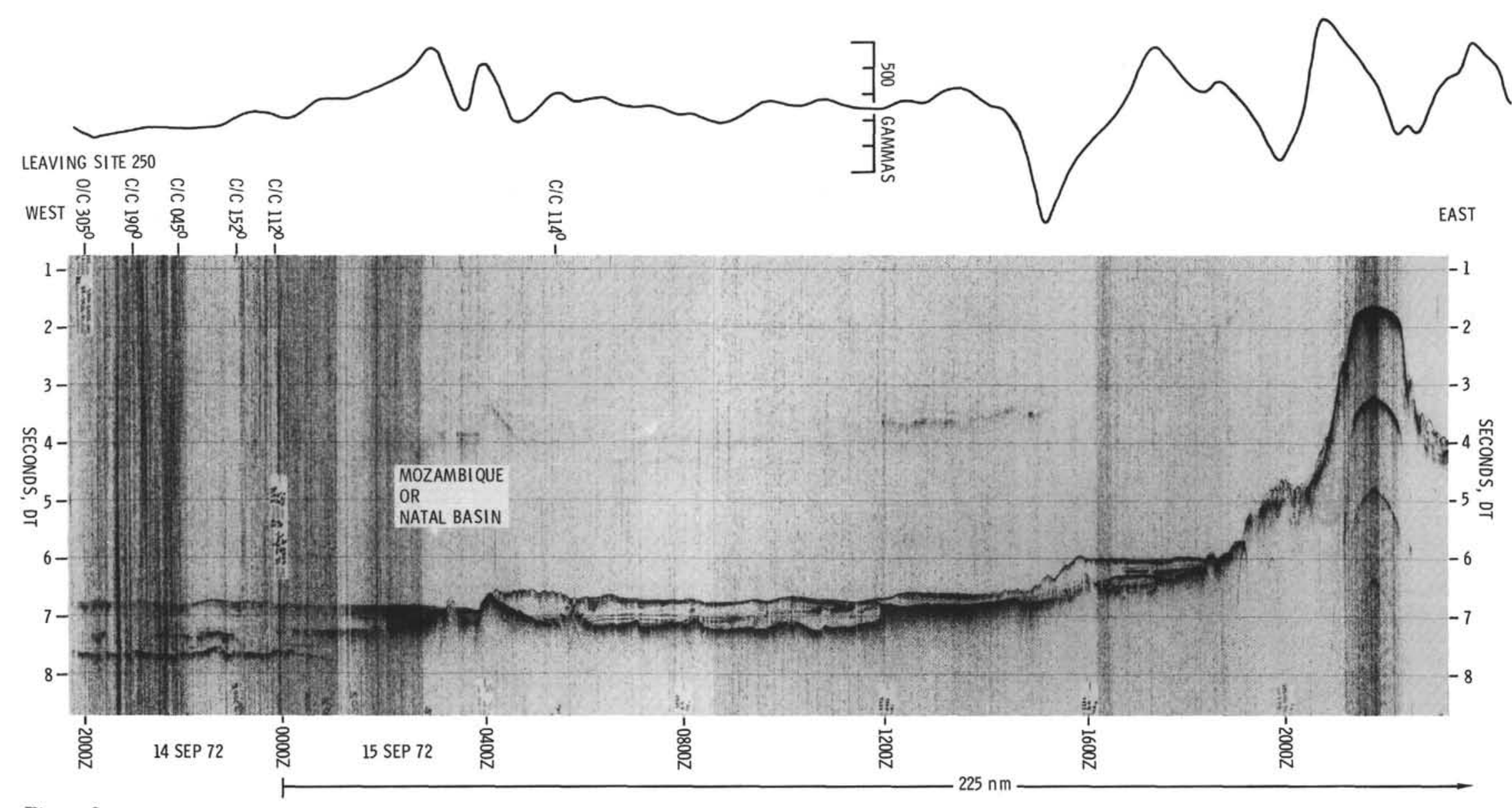

Figure 3. 

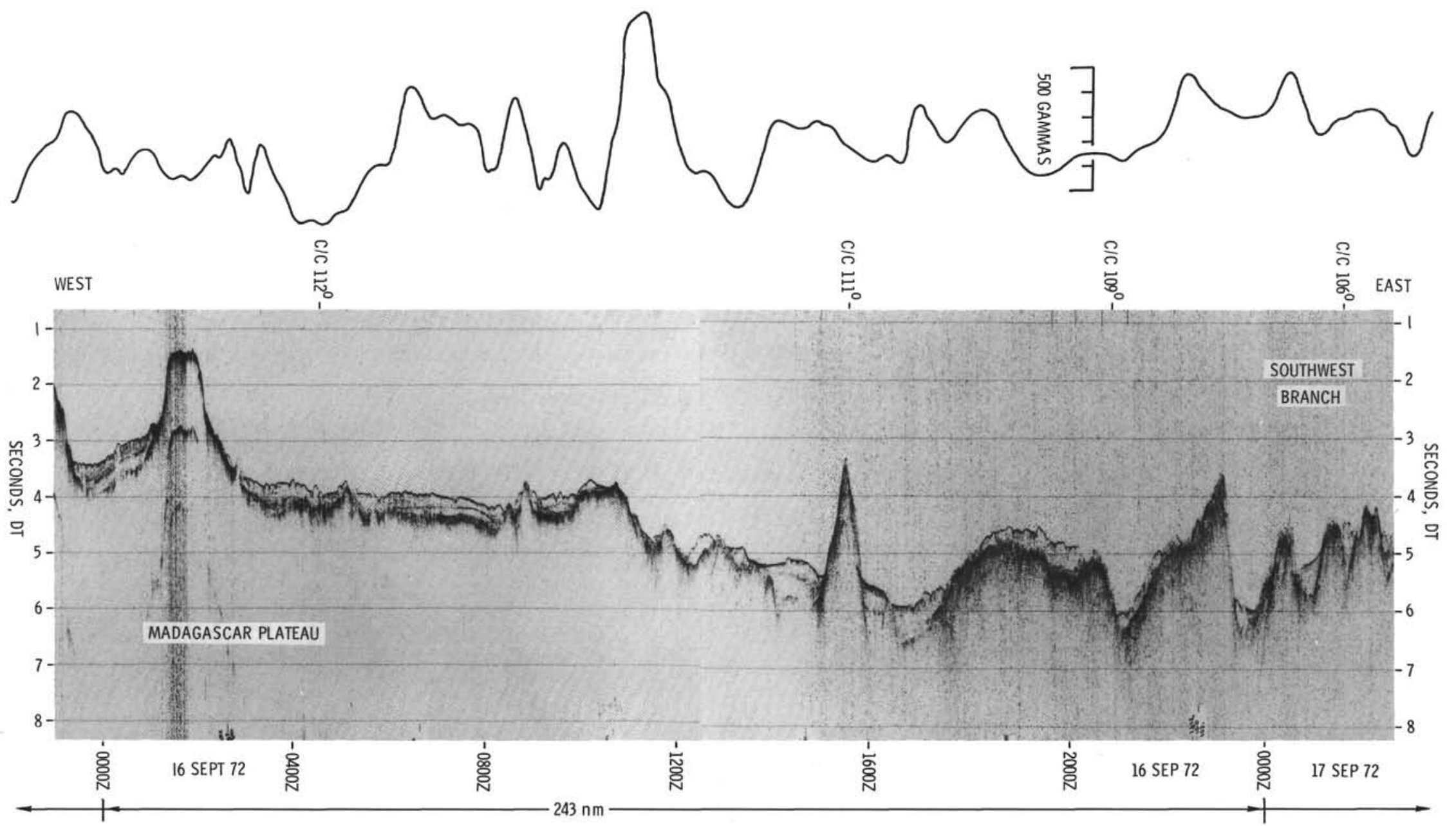

Figure 3. (Continued). 


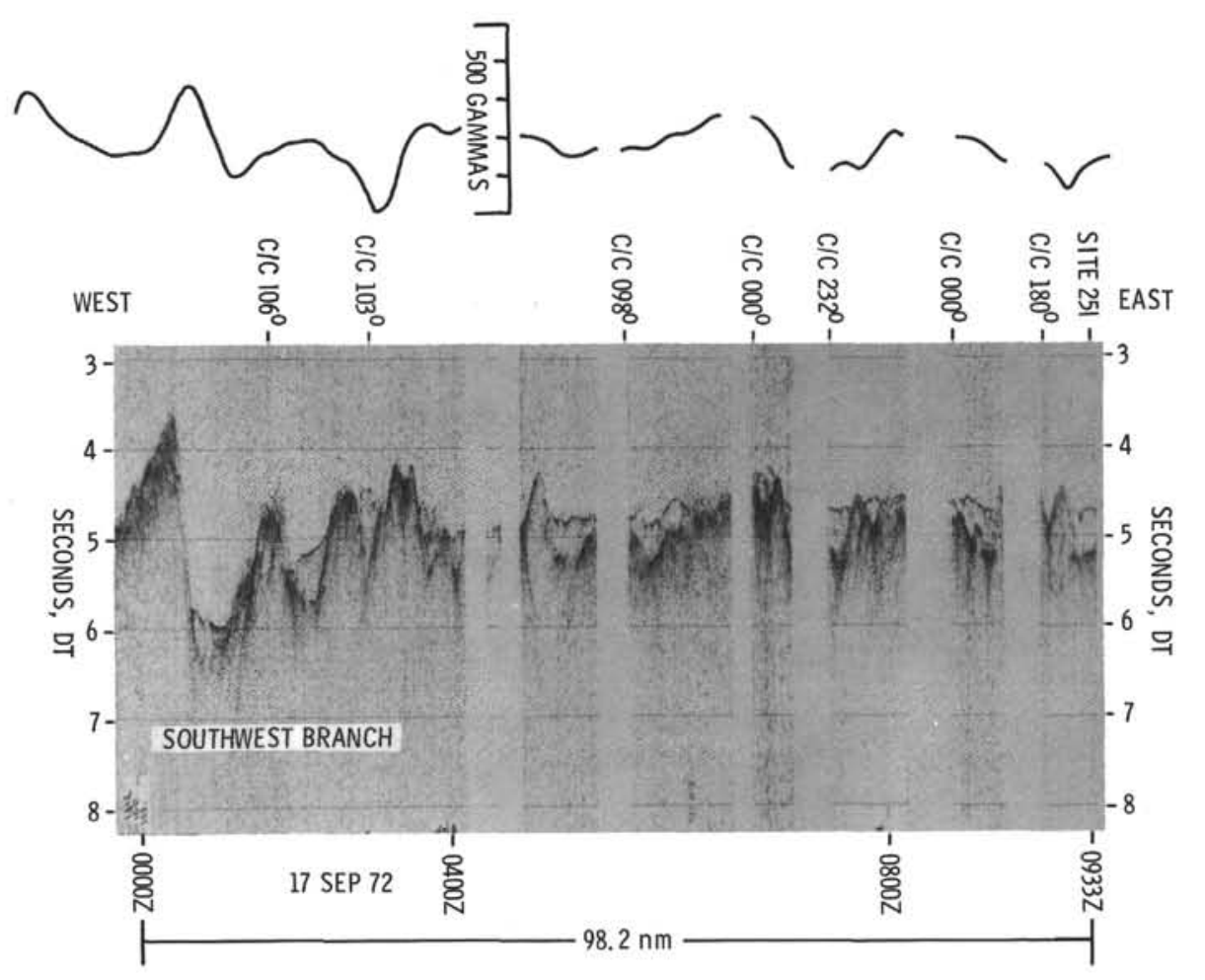

Figure 3. (Continued). 


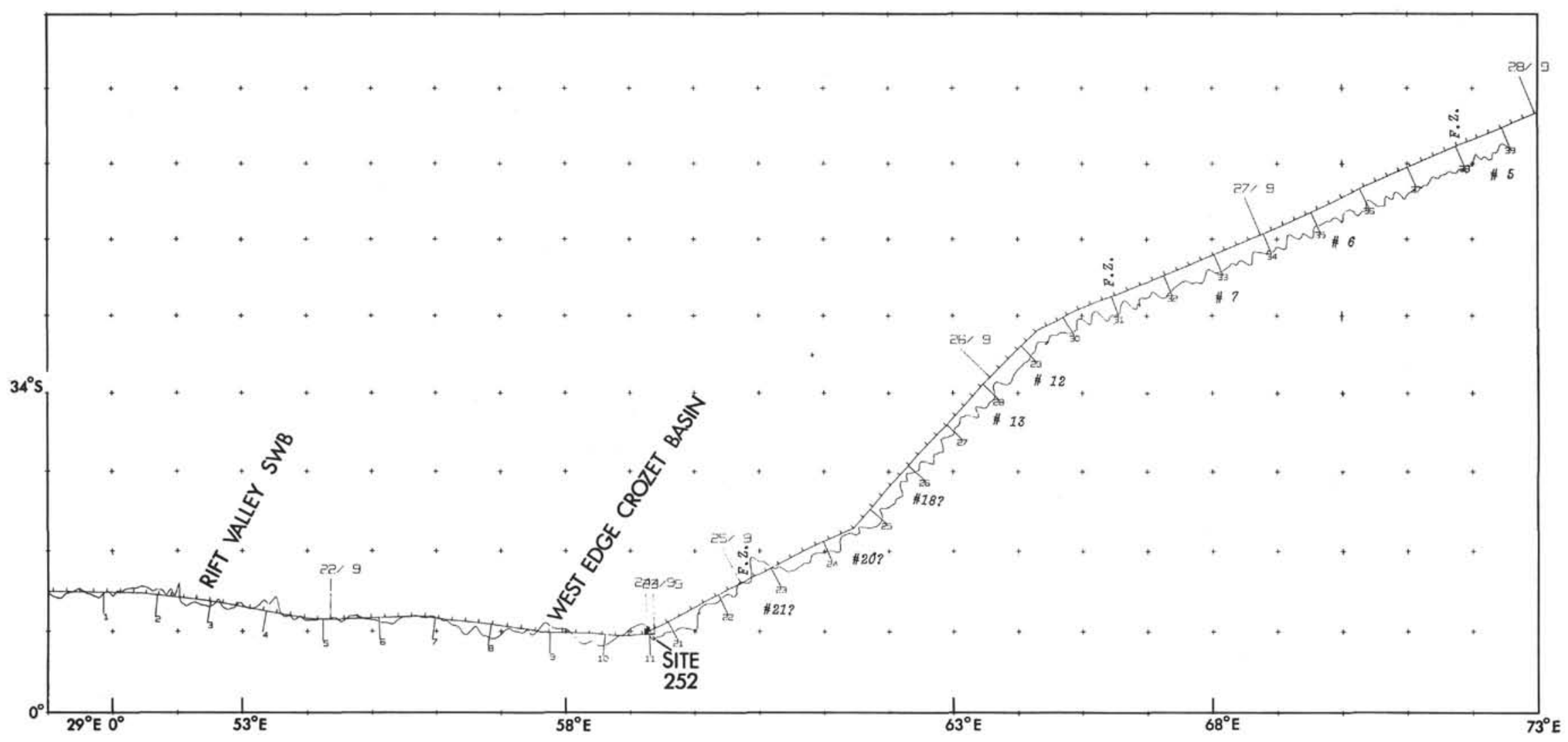

Figure 4. 


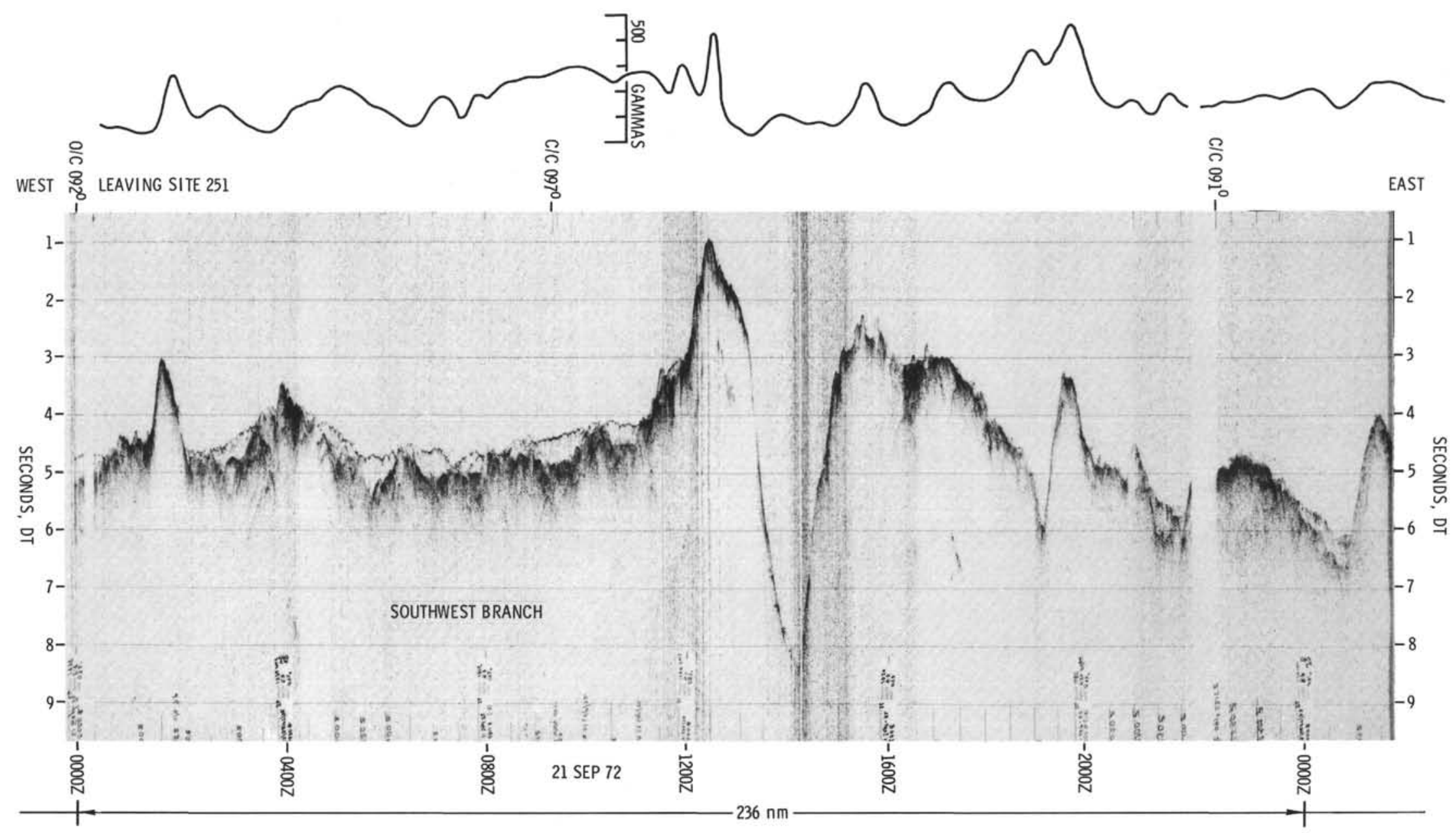

Figure 5. 


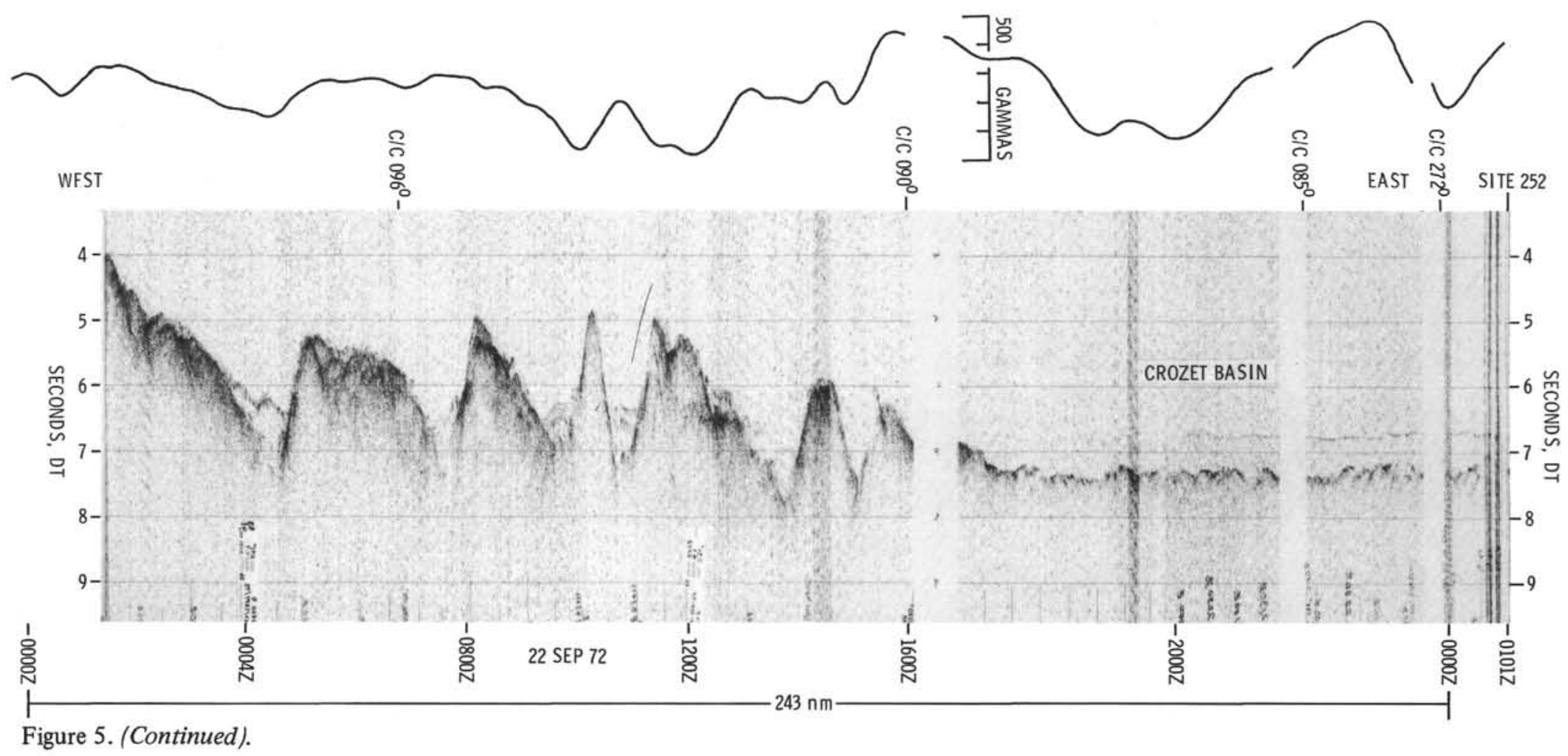




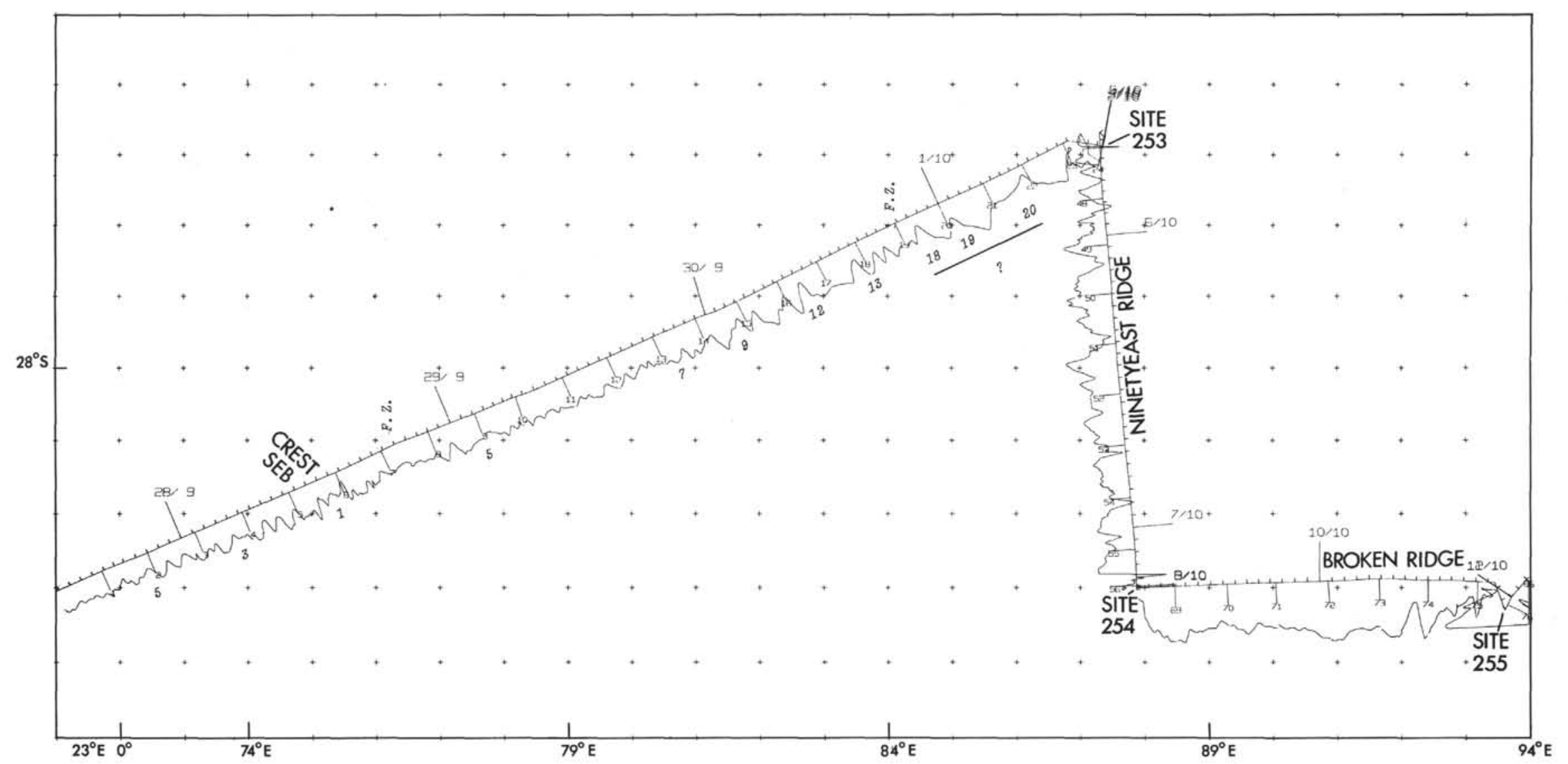

Figure 6. 


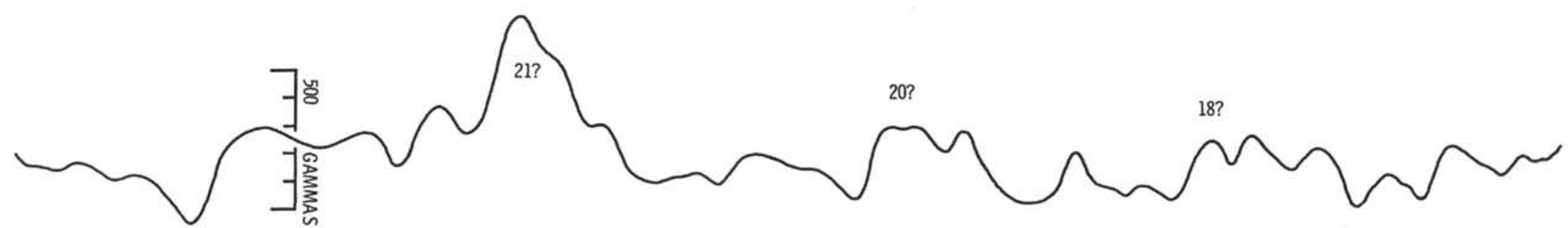

SOUTHWEST 咅 LEVING SITE 252

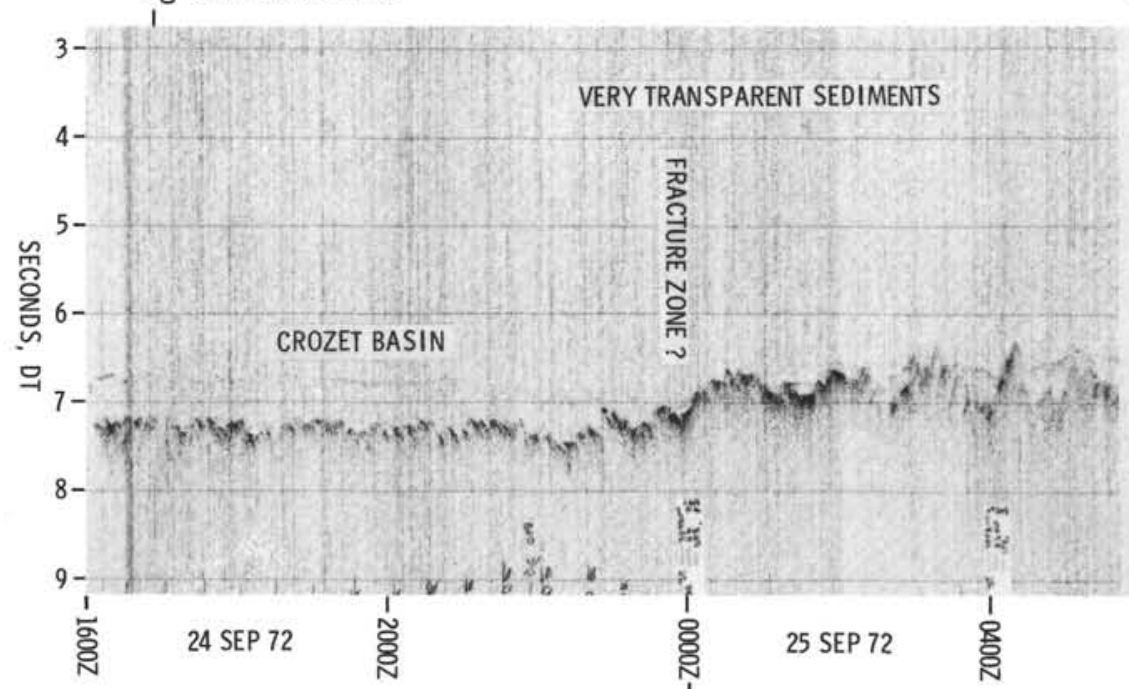

Figure 7.

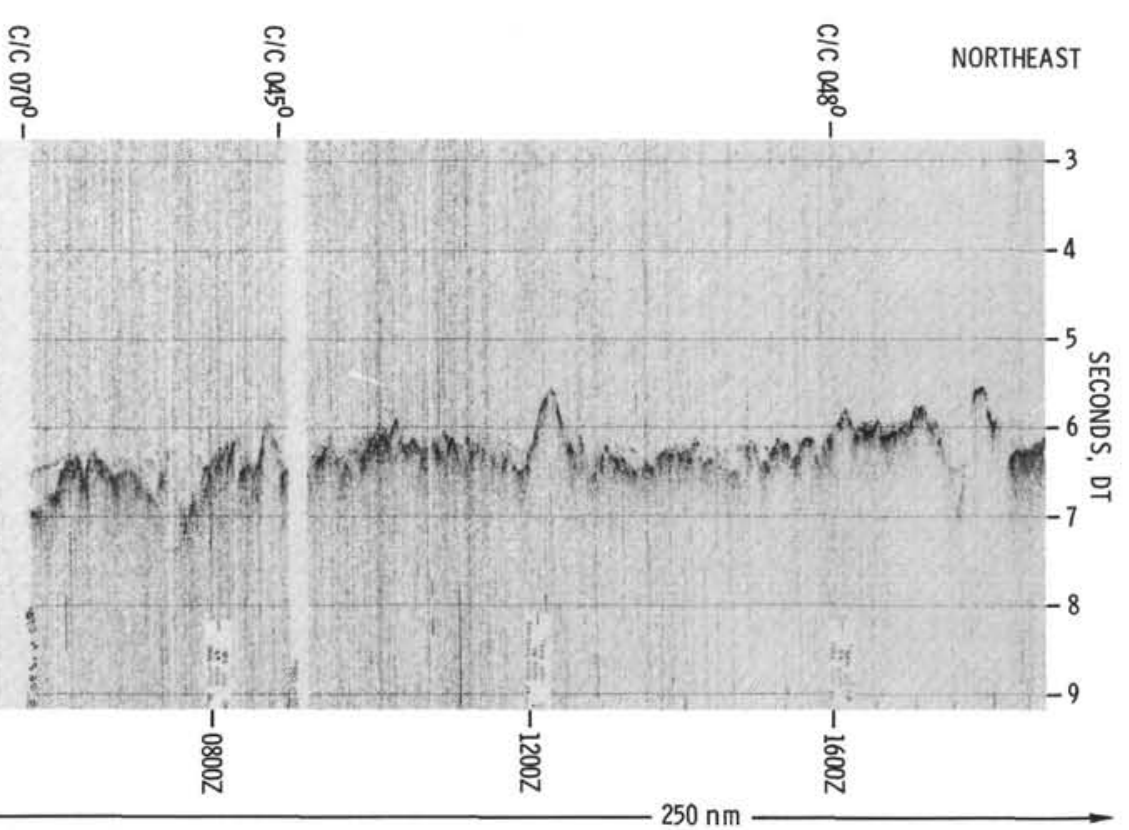

$250 \mathrm{~nm} \longrightarrow$ 


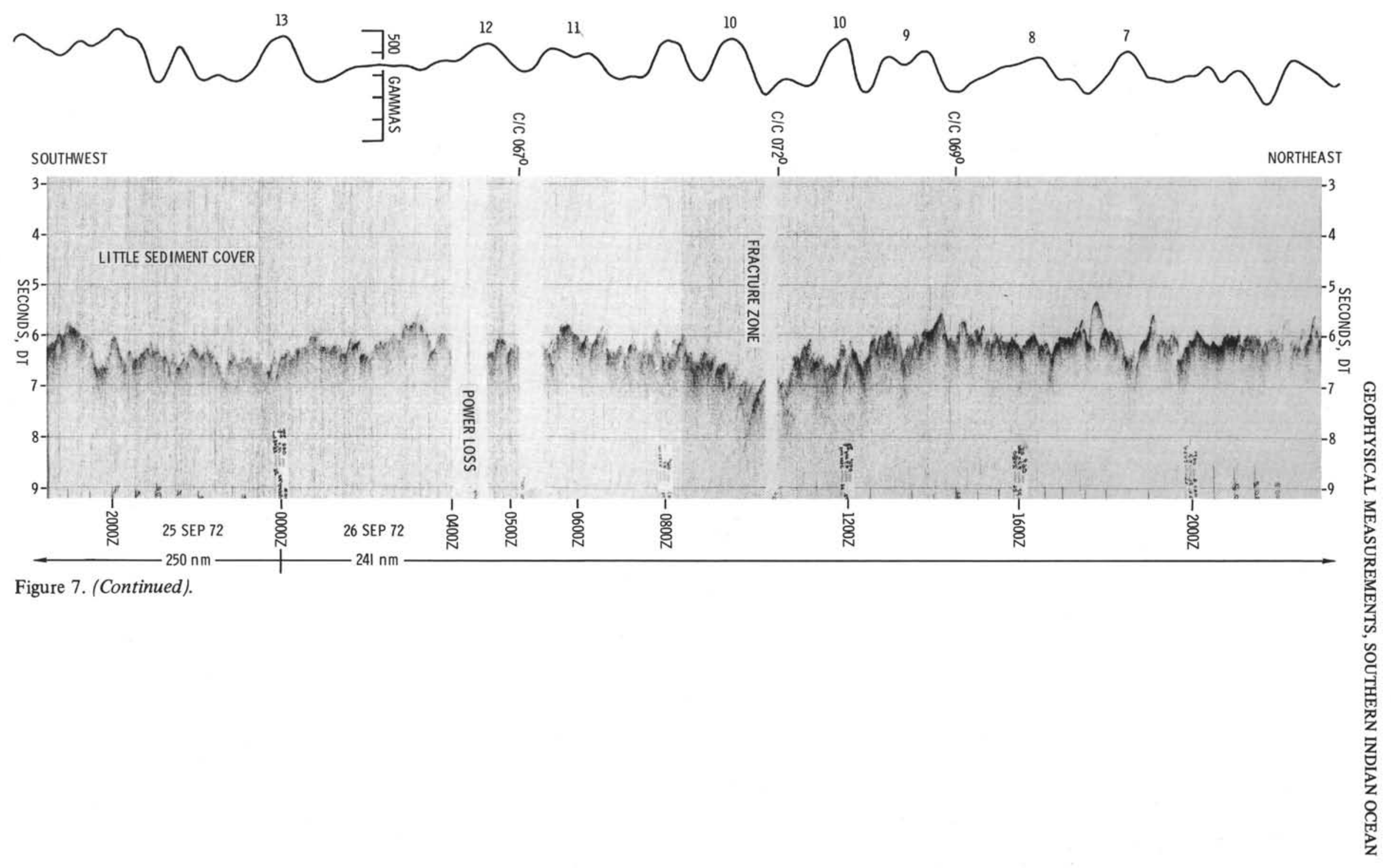



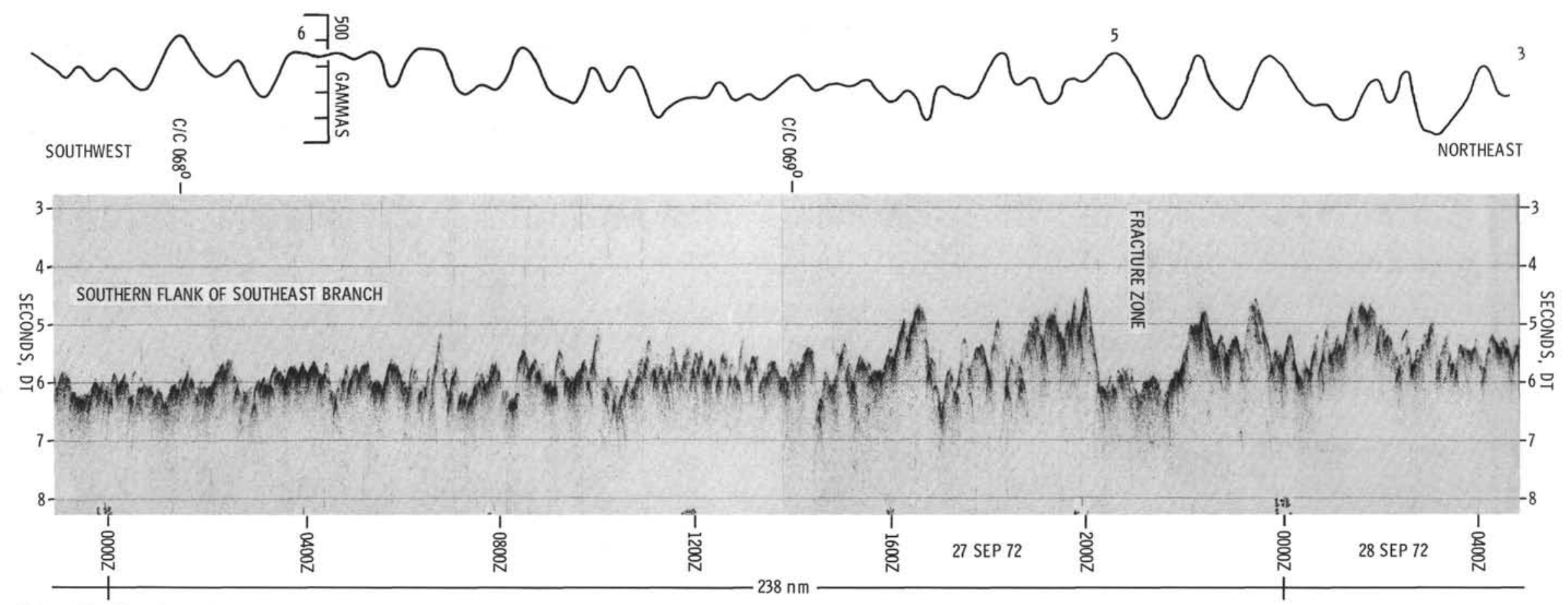

Figure 7. (Continued). 


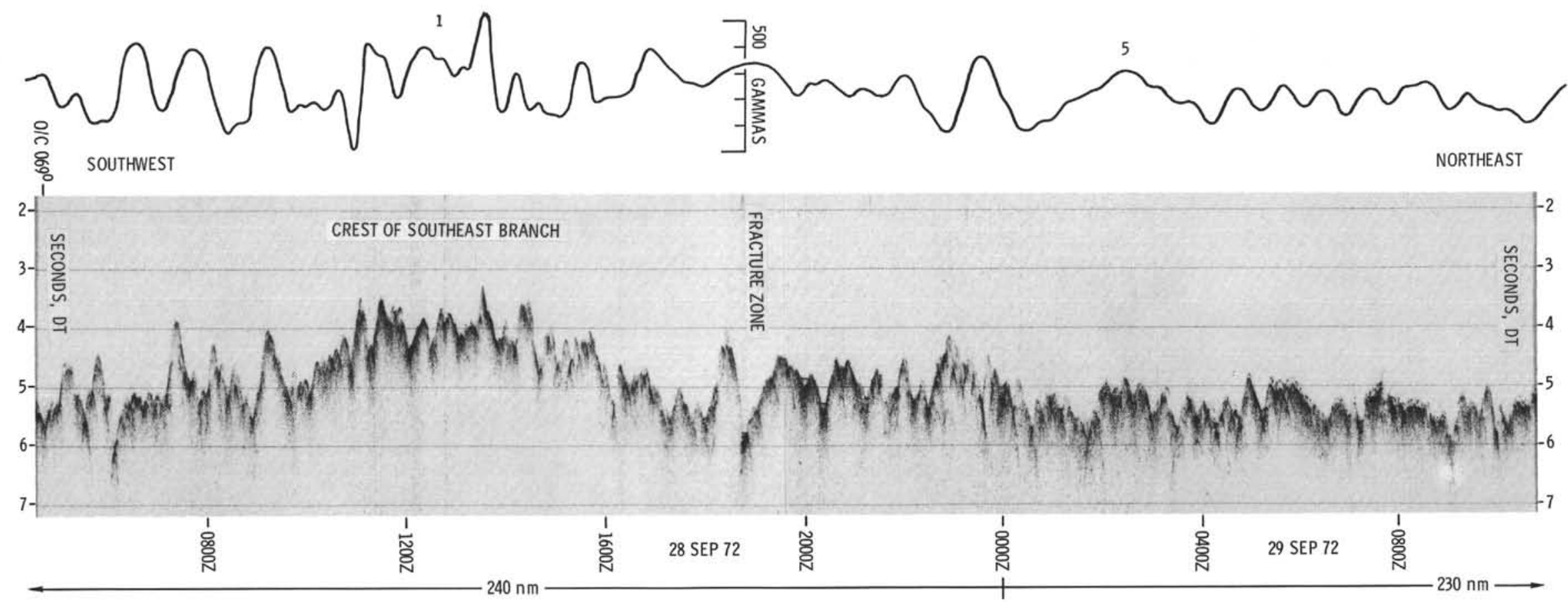

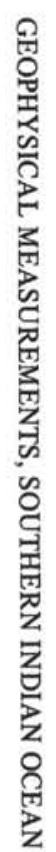




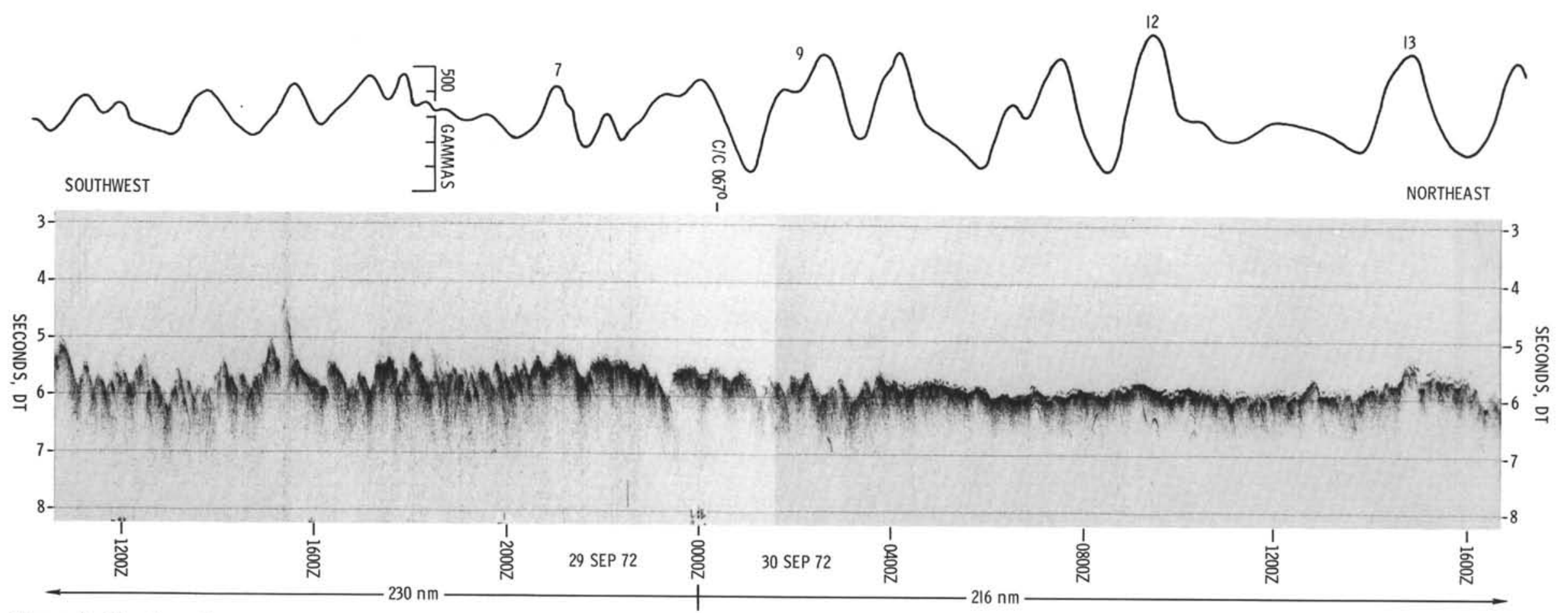

Figure 8. (Continued). 


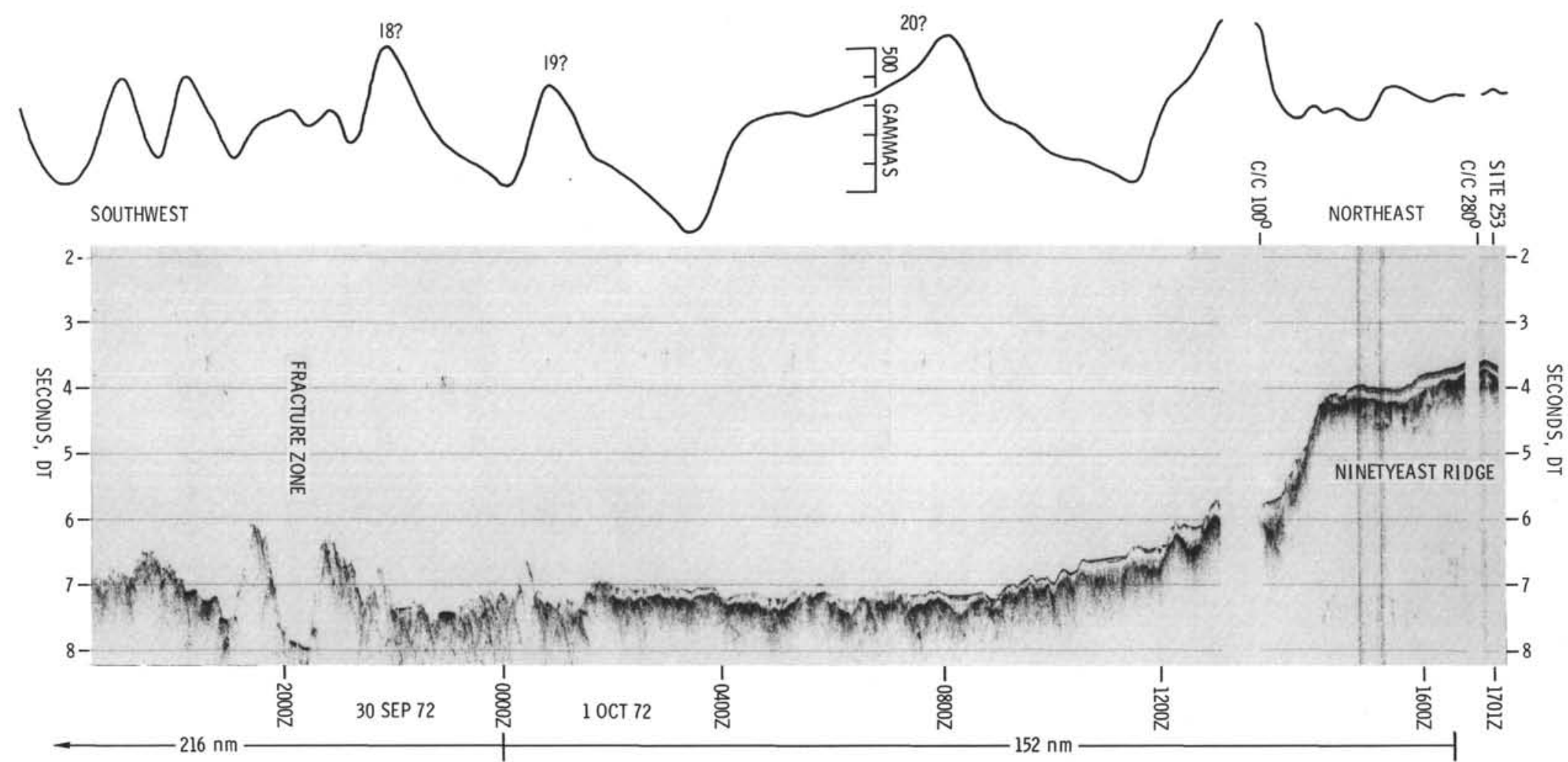

Figure 8. (Continued). 


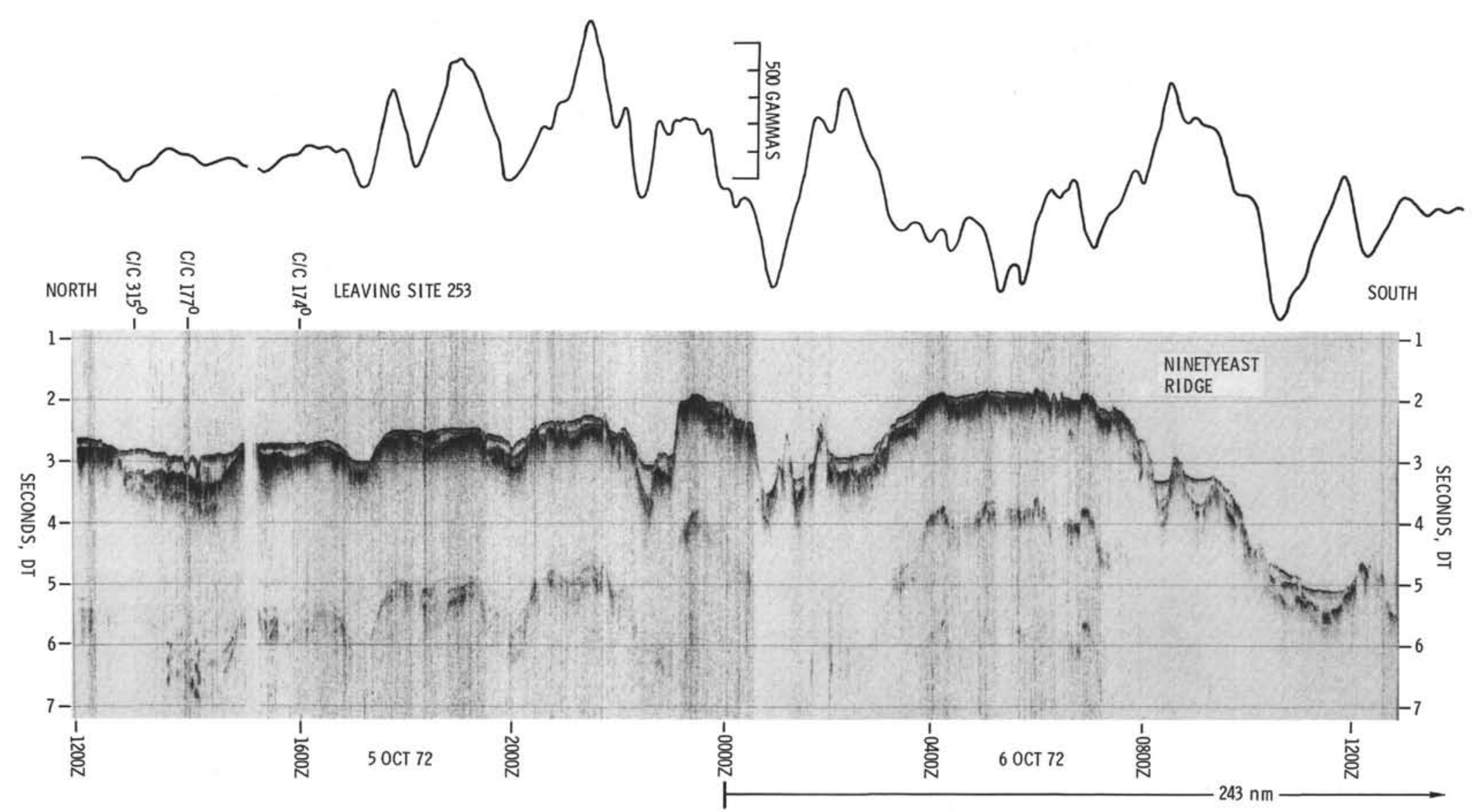

Figure 9. 


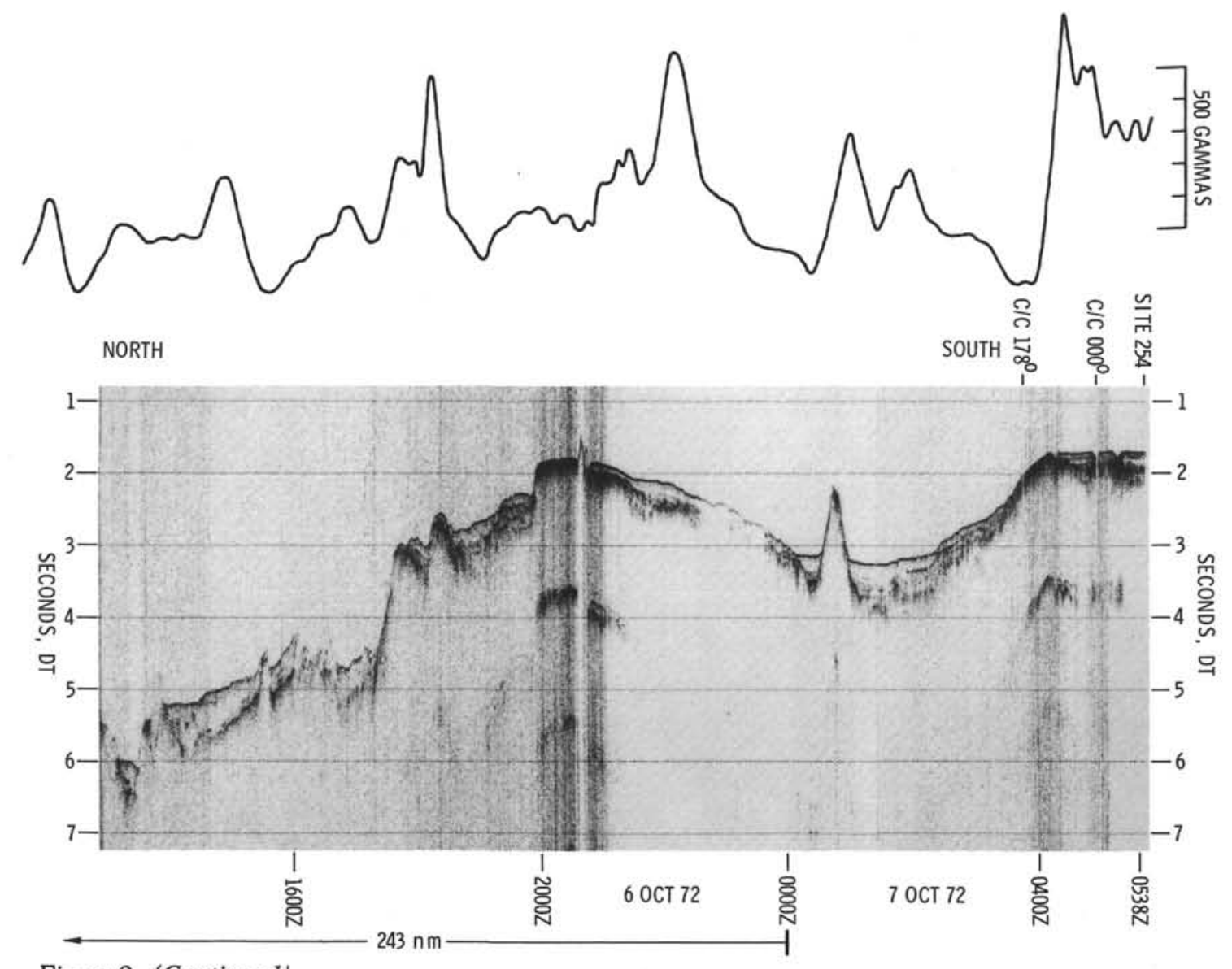

Figure 9. (Continued). 


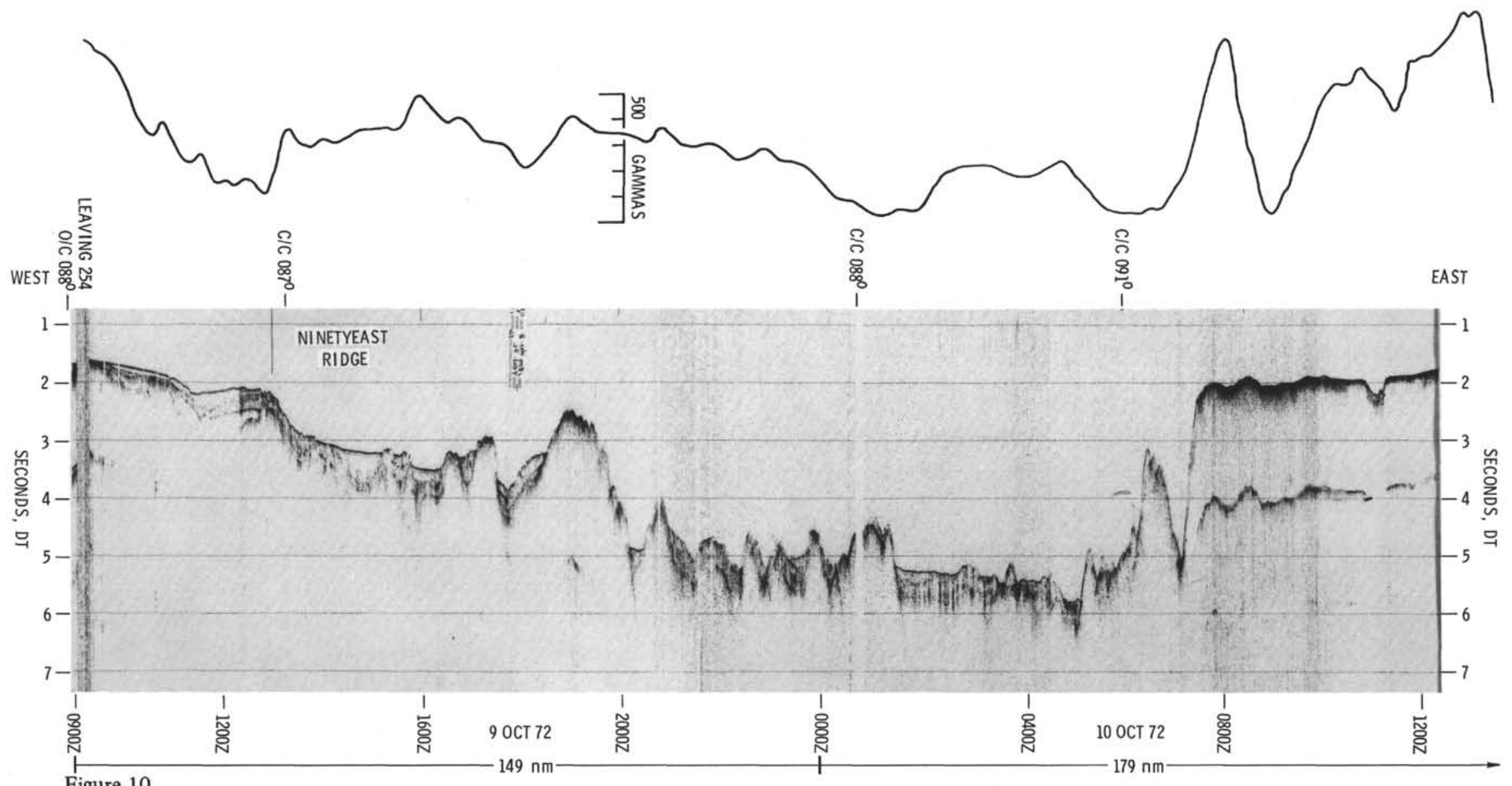

Figure 10. 


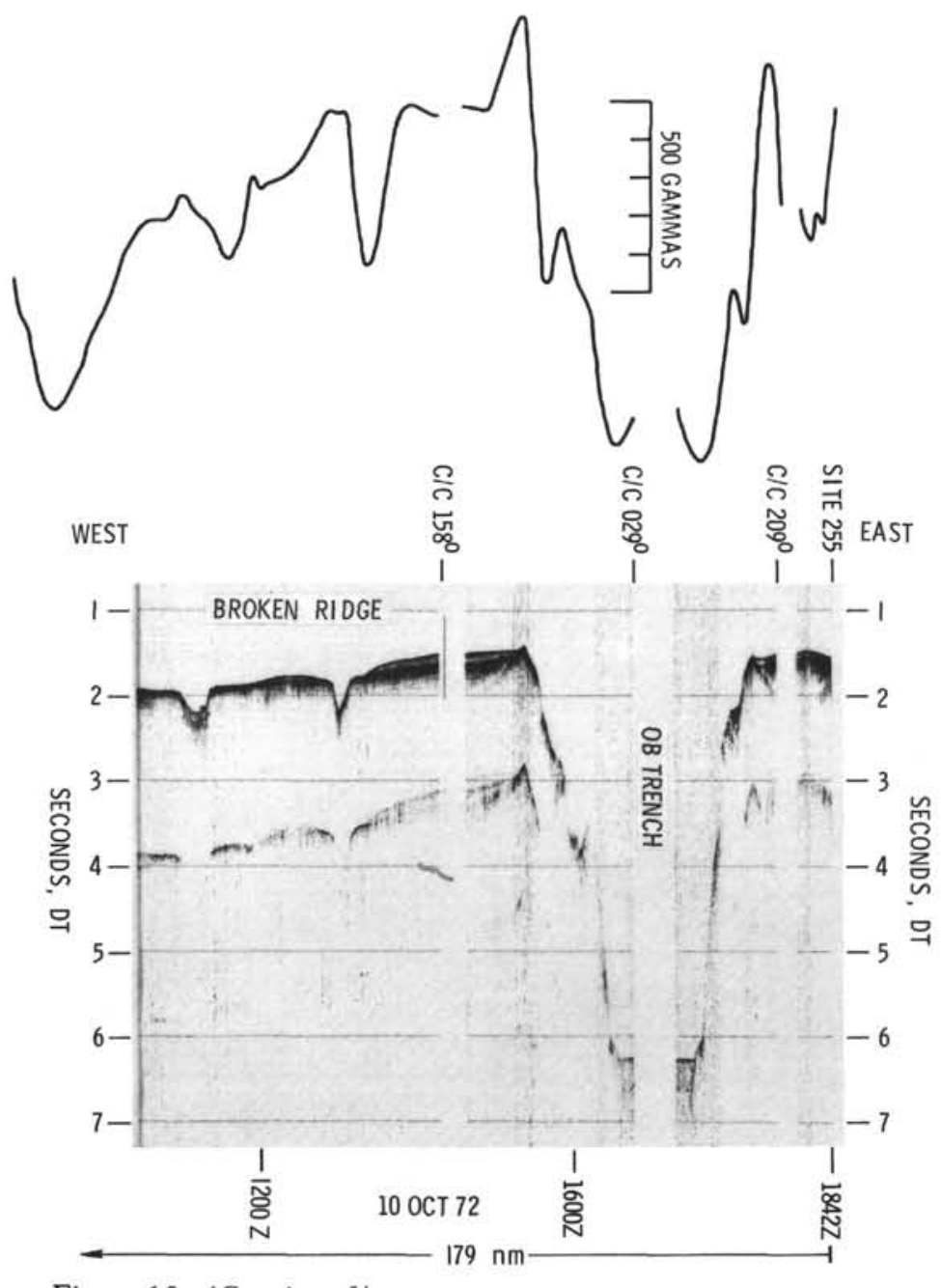

Figure 10. (Continued). 


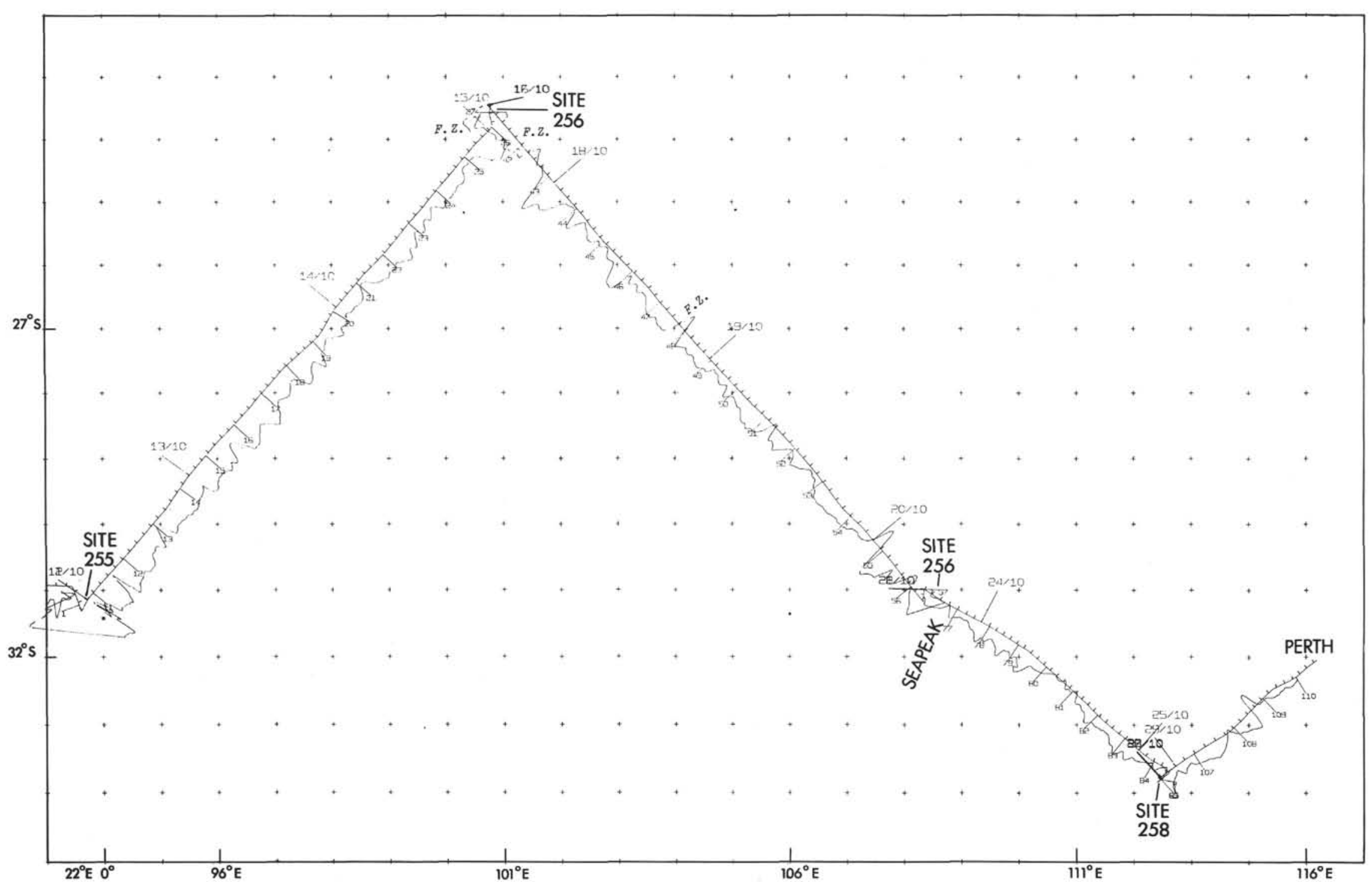

Figure 11 . 


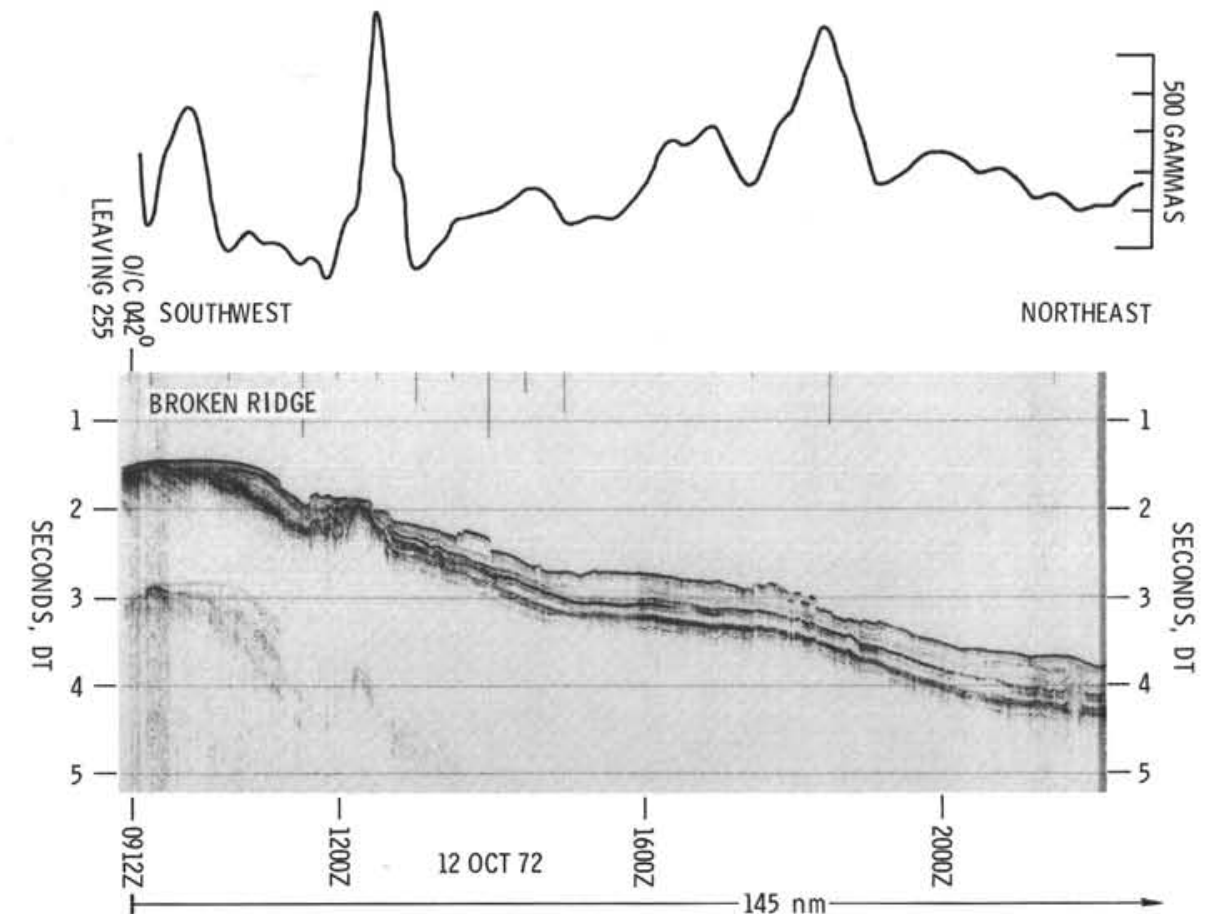

Figure 12. 


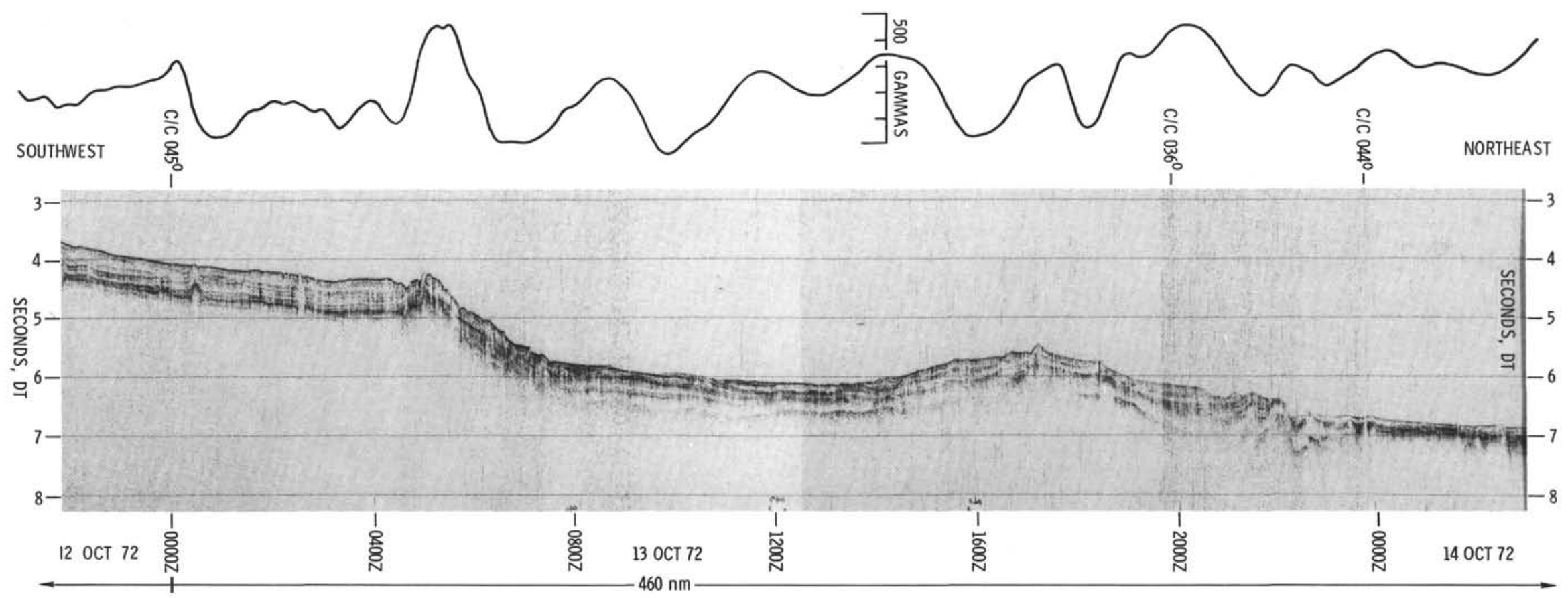

Figure 12. (Continued). 

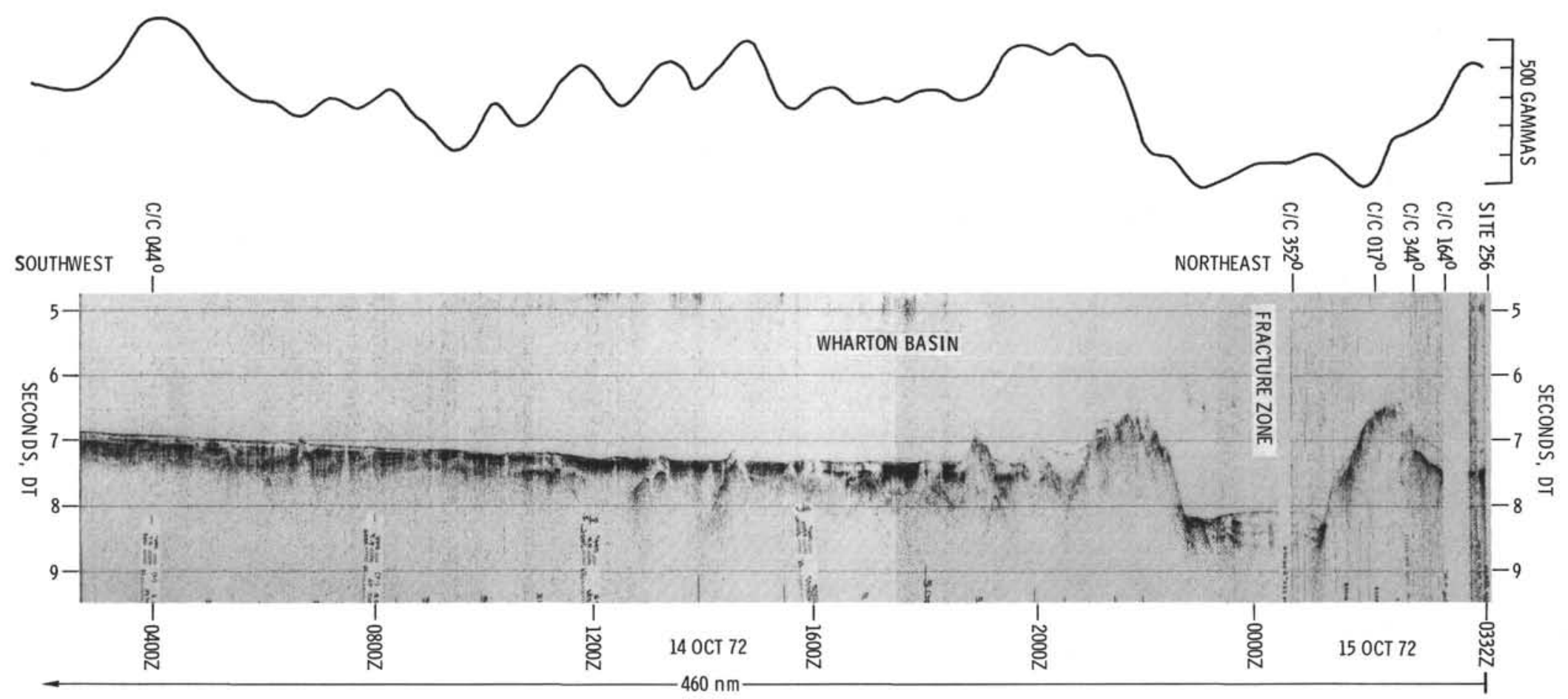

Figure 12. (Continued). 


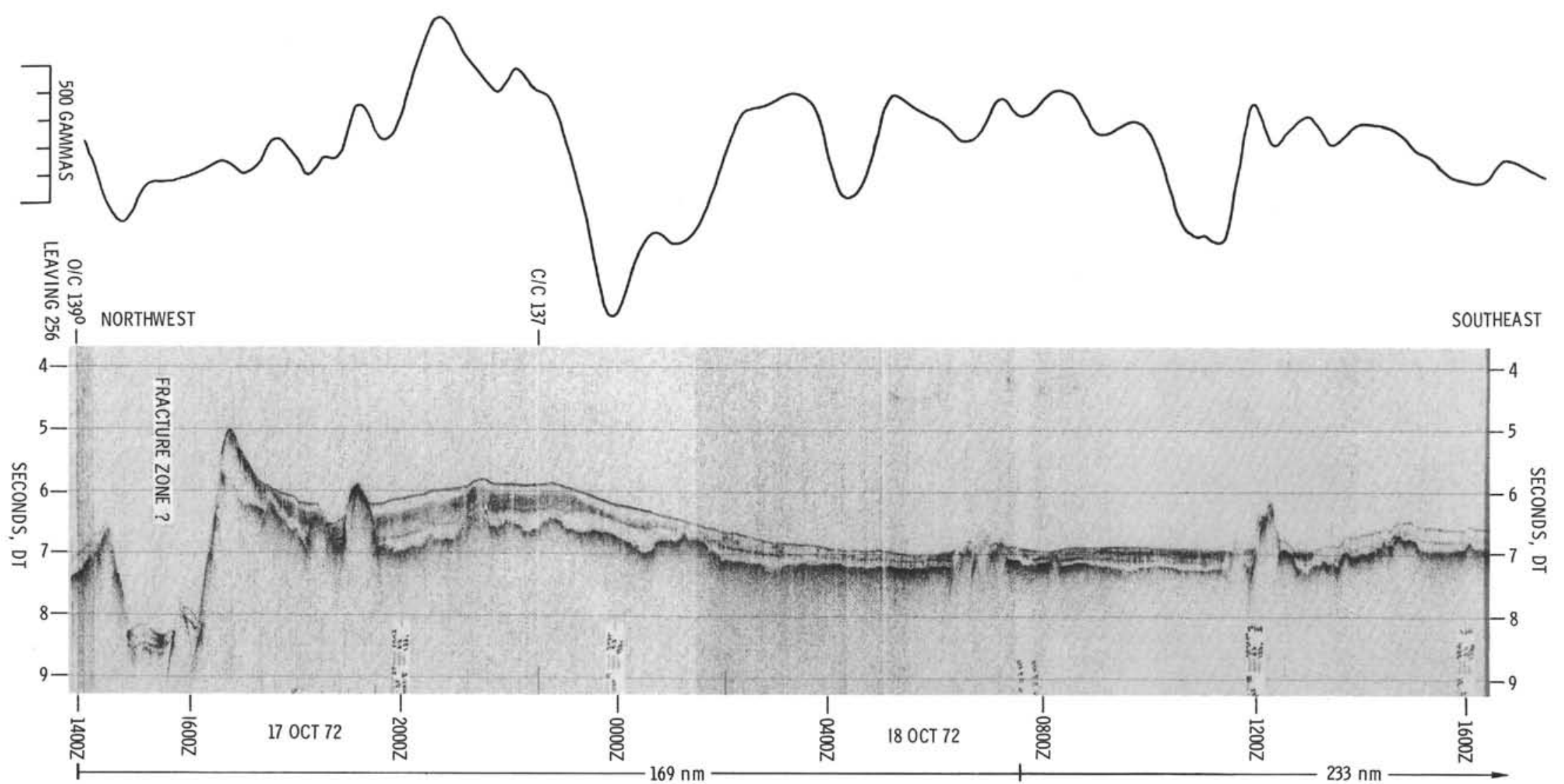

Figure 13. 

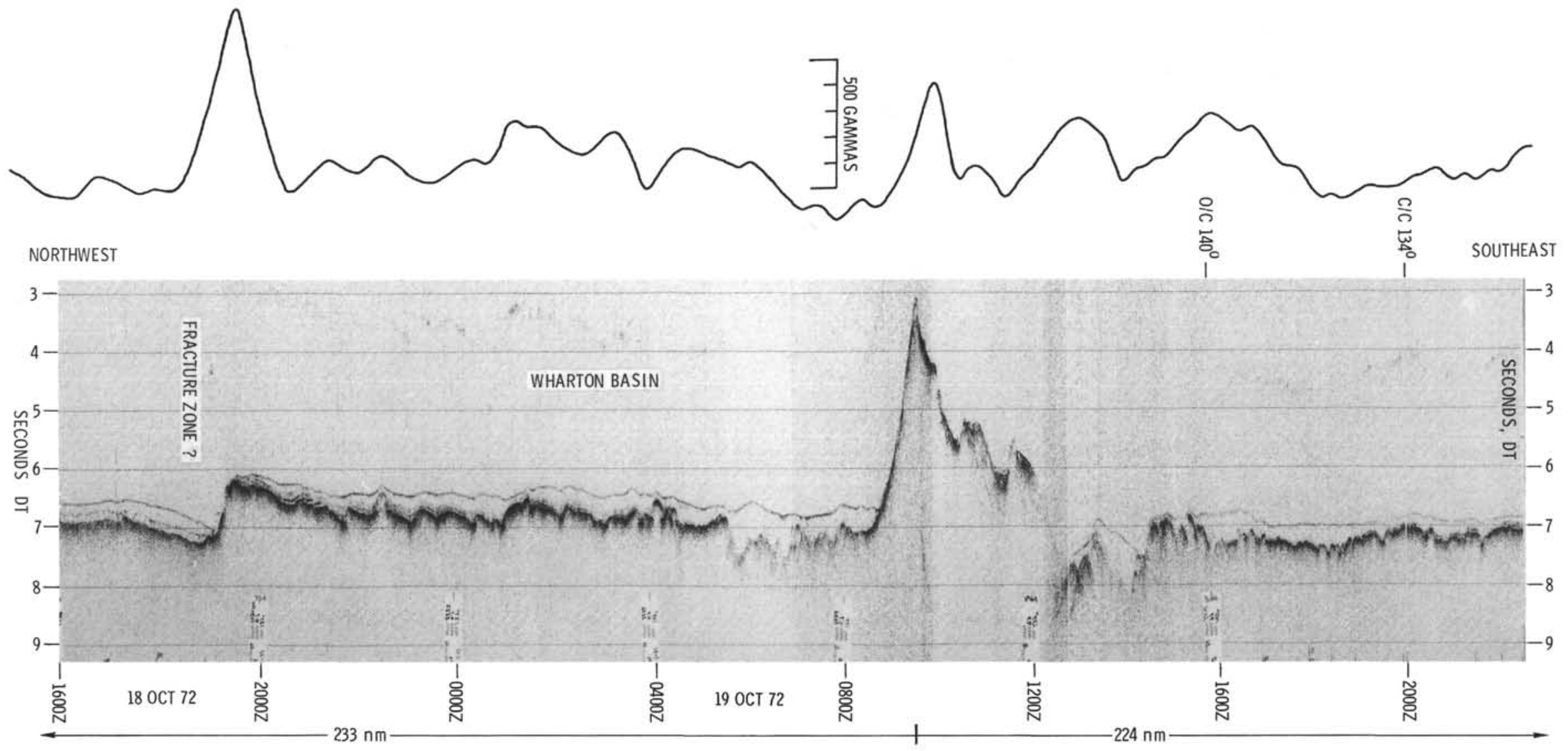

Figure 13. (Continued). 


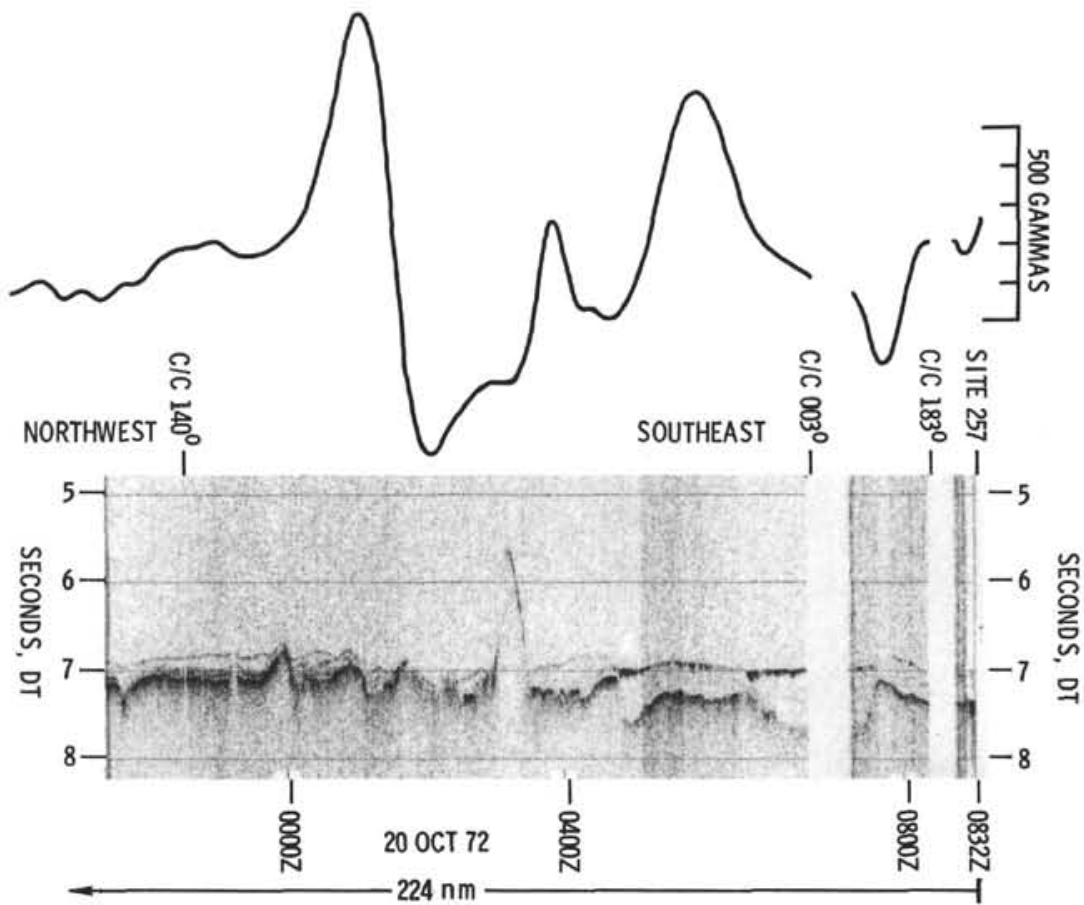

Figure 13. (Continued). 


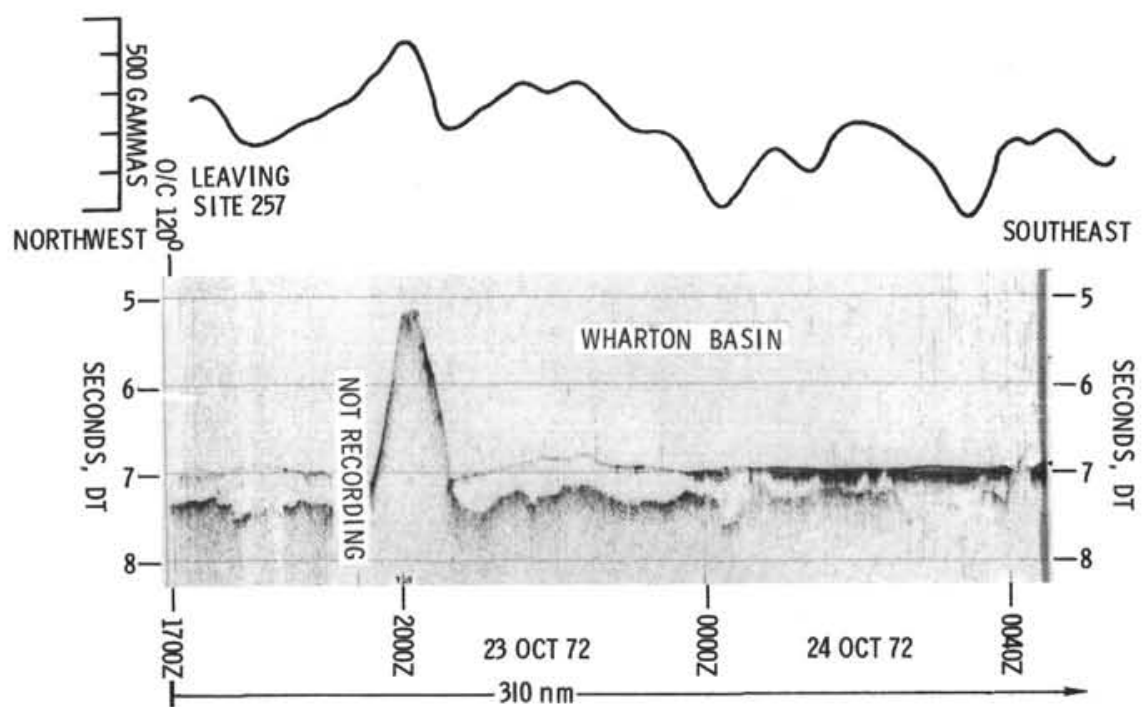

Figure 14. 


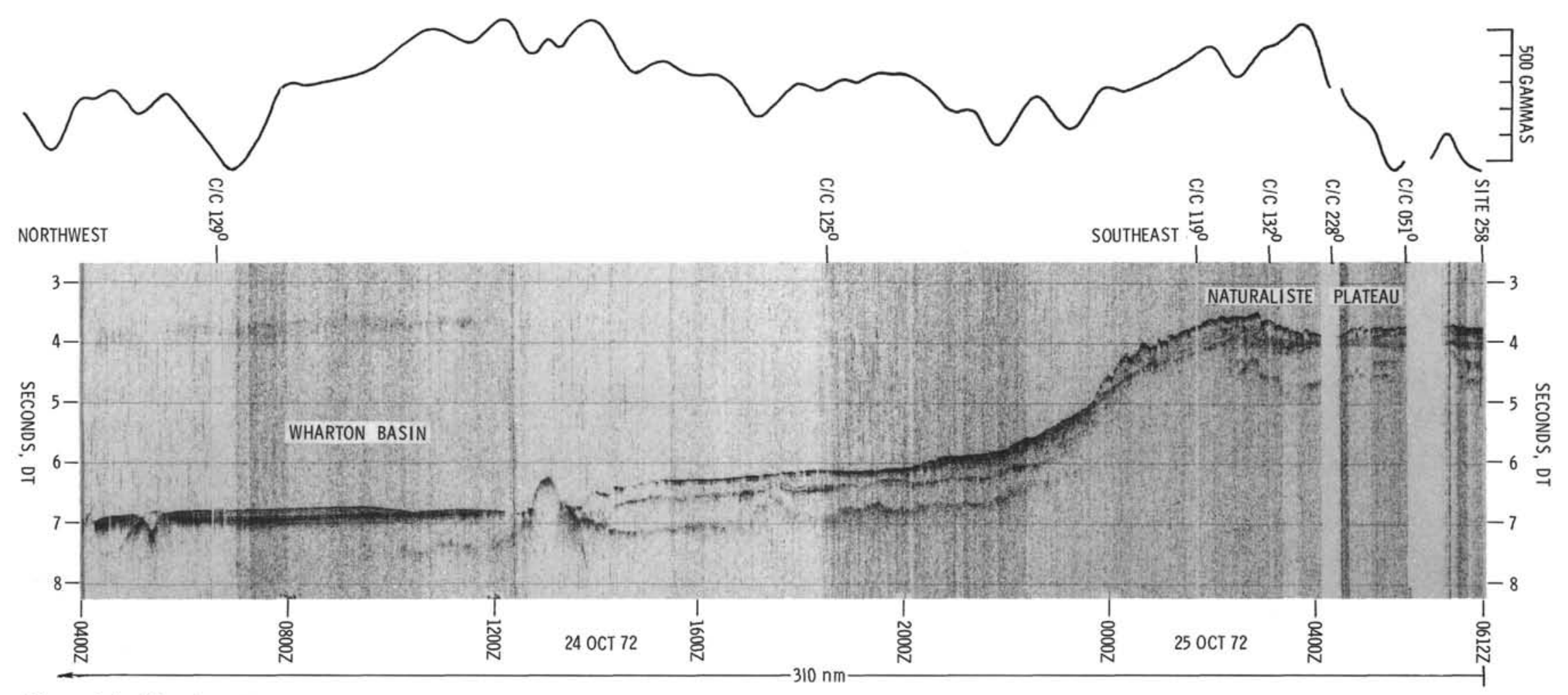

Figure 14. (Continued). 


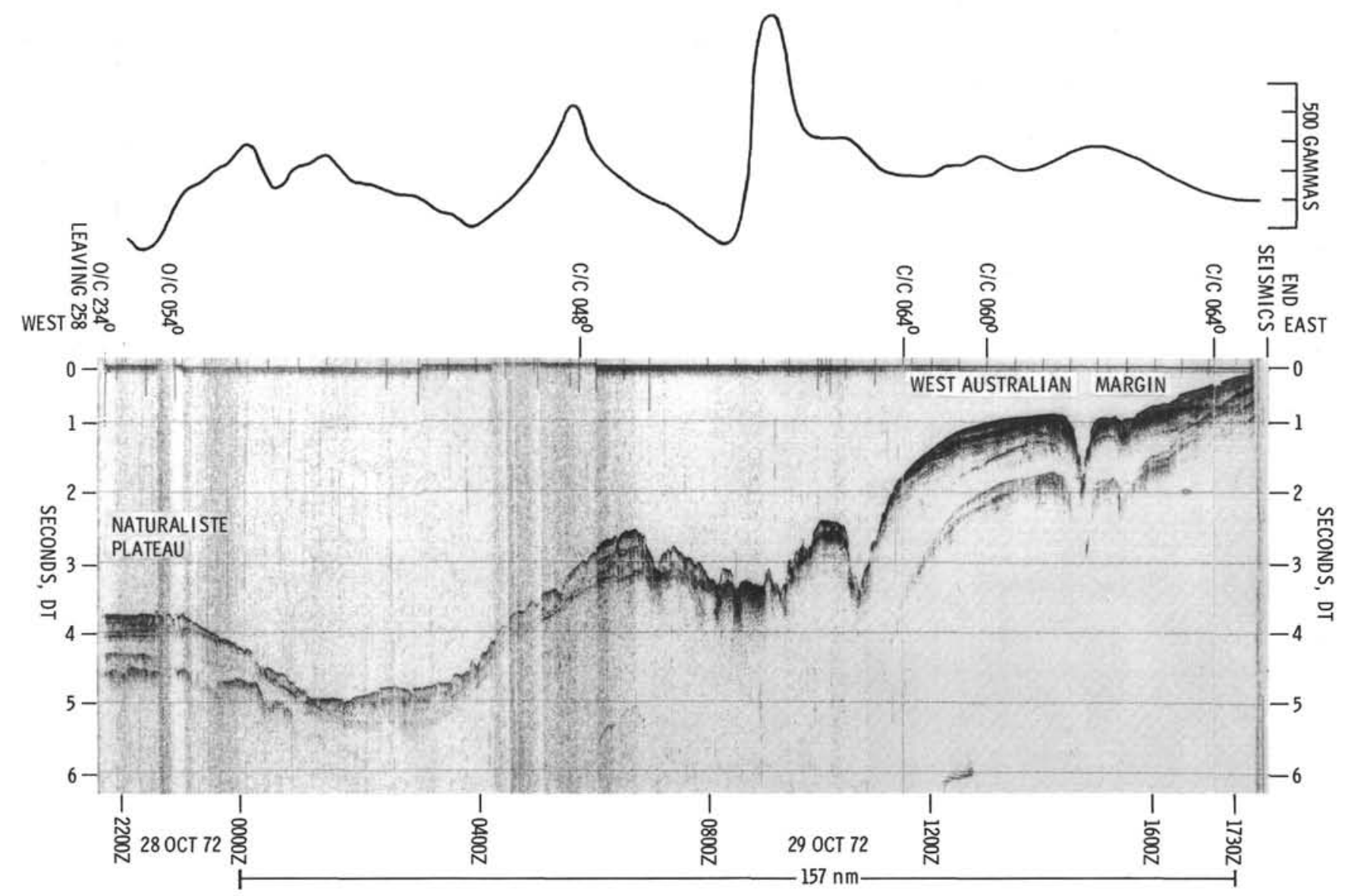

Figure 15. 